\title{
The stability of sodalite in the system $\mathrm{NaAlSiO}_{4}-\mathrm{NaCl}^{*}$
}

\author{
Z. D. Sharp ${ }^{1, \dagger}$, G. R. HelfFrich ${ }^{2}$, S. R. BOHLEN ${ }^{3,4}$ and E. J. ESSENE ${ }^{4}$ \\ ' Geophysical Laboratory, Carnegie Institution of Washington, 2801 Upton Street, N.W., Washington, D.C. 20008, U.S.A. \\ ${ }^{2}$ Department of Geological Sciences, Northwestern University, Evanston, IL 60208, U.S.A. \\ ${ }^{3}$ Department of Earth and Space Sciences, S.U.N.Y, Stony Brook, NY 11794, U.S.A. \\ ${ }^{4}$ Department of Geological Sciences, University of Michigan, Ann Arbor, MI 48109, U.S.A.
}

(Received May 5, 1988; accepted in revised form May 5, 1989)

\begin{abstract}
The reaction sodalite $=\beta$-nepheline $+\mathrm{NaCl}(s)$ was reversed in solid-medium apparatus $(923$ $\mathrm{K}, 7.6-8.0 \mathrm{kbar} ; 973 \mathrm{~K}, 7.4-7.6 \mathrm{kbar} ; 1073 \mathrm{~K}, 7.8-8.0 \mathrm{kbar} ; 1173 \mathrm{~K}, 8.4-8.6 \mathrm{kbar}$ ) and the reaction sodalite $=$ carnegieite $+\mathrm{NaCl}(l)$ was reversed at 1 bar $(1649-1652 \mathrm{~K})$. The calculated slope for the first reaction is $-11 \mathrm{bar} / \mathrm{K}$ compared to the experimentally constrained slope above $973 \mathrm{~K}$ of $+5 \mathrm{bar} / \mathrm{K}$. This major discrepancy can be eliminated if the entropy of sodalite $\left(\mathrm{Na}_{8} \mathrm{Al}_{6} \mathrm{Si}_{6} \mathrm{O}_{24} \mathrm{Cl}_{2}\right)$ is $61.7 \mathrm{~J} / \mathrm{mol} \cdot \mathrm{K}$ greater than the measured value of $848.1 \pm 4.0 \mathrm{~J} / \mathrm{mol} \cdot \mathrm{K}$ at $298.15 \mathrm{~K}$. This entropy contribution is equal to that expected from $58 \%$ disorder of $\mathrm{Al}$ and $\mathrm{Si}$ on the tetrahedral sites, but could also be caused by a reversible phase change. The experimental reversals between $923 \mathrm{~K}$ and $973 \mathrm{~K}$ can be fit with a $d P / d T$ of $-11 \mathrm{bar} / \mathrm{K}$, suggesting that the excess entropy for sodalite is present only above $923 \mathrm{~K}$. A phase diagram for the $\mathrm{NaAlSiO}_{4}-\mathrm{NaCl}$ system that is consistent with the measured thermochemical data and the experiments between 973 and $1650 \mathrm{~K}$ can be generated if the $61.7 \mathrm{~J} / \mathrm{mol} \cdot \mathrm{K}$ entropy contribution is included in the $S_{298}^{0}$ of sodalite. This entropy contribution must be removed below $973 \mathrm{~K}$ for the experiments to fit with calculations. Previously unreported thermodynamic data estimated in this study are $\Delta G_{298}^{0}$ for sodalite $(-12697 \mathrm{~kJ} / \mathrm{mol})$ and carnegieite $\left(\mathrm{NaAlSiO}_{4}\right)(-1958 \mathrm{~kJ} / \mathrm{mol}), S_{298}^{\mathrm{o}}$ of carnegieite $(129.6 \mathrm{~J} / \mathrm{mol} \cdot \mathrm{K})$ and compressibility of $\mathrm{NaCl}_{\text {liquid }}\left(V_{298}^{\mathrm{P}}\left(\mathrm{cm}^{3}\right)=31.6 \cdot\left[1-24.7 \cdot 10^{-3} \cdot P\right.\right.$ $\left.\left.+800 \cdot 10^{-6} \cdot P^{2}\right]\right)(T$ in $\mathrm{K} ; P$ in kbar $)$.

Sodalite is a high-temperature, low-pressure phase, stable well above the solidus in sodic silica-undersaturated magmas enriched in $\mathrm{NaCl}$, and its presence constrains $\mathrm{NaCl}$ activities in magmas. Estimates of minimum $\mathrm{NaCl}(l)$ activities in the Mont St-Hilaire sodalite syenites are 0.05 at $1073 \mathrm{~K}$ and 0.13 at $1273 \mathrm{~K}$. Density calculations are consistent with the field observations that sodalite phenocrysts will float in a nepheline syenite liquid. This explains the enrichment of sodalite in the upper levels of the sodalite syenites at Mont St-Hilaire and elsewhere.
\end{abstract}

\section{INTRODUCTION}

THE PRESENCE AND composition of fluids in high-temperature, geological environments have a strong effect on the physical and chemical properties of solids and melts and will in large part determine the final mineral assemblage of rocks exposed at the Earth's surface. Measurement of fluid inclusion salinities has been used widely as an indication of fluid salinity at the time of crystallization of the host mineral (e.g., ROEDDER, 1984); however, these fluids are often trapped or lastmodified well after crystallization and need not constrain conditions extant at the time of the crystallization of the host. Phase equilibria have only rarely been used to calculate fluid salinities because of a lack of mineral assemblages that buffer the activity of $\mathrm{NaCl}$. One of the few rock-forming minerals that contains chlorine as an essential component is sodalite $\left(\mathrm{Na}_{8} \mathrm{Al}_{6} \mathrm{Si}_{6} \mathrm{O}_{24} \mathrm{Cl}_{2}\right)$. It is restricted to rocks undersaturated in $\mathrm{SiO}_{2}$ and found most commonly in hdyrothermally altered

\footnotetext{
* Contribution from the Geophysical Laboratory, Carnegie Institution of Washington, and \#461 from the Mineralogical Laboratory, Department of Geological Sciences, University of Michigan, Ann Arbor, MI 48109, U.S.A.

$\dagger$ Present address: Section Sciences de la Terre, Institut de Minéralogie, UNIL BFSH 2, CH-1015 Lausanne, Switzerland.

$\ddagger$ Present address: United States Geological Survey, MS-910, 345 Middlefield Road, Menlo Park, CA 94025, U.S.A.
}

igncous rocks (DEER et al., 1963; CARMICHAEL et al., 1974), although it is occasionally reported as a primary phase in alkali layered intrusions (e.g., UsSING, 1912; VLASOV et al., 1966), in metamorphic rocks (SIMPSON and OTTO, 1960) and in meteorites (GROSSMAN and STEELE, 1976; LUMPKIN, 1980). With accurate thermodynamic data for phases in the $\mathrm{NaAlSiO}_{4}-\mathrm{NaCl}$ system, the activity of $\mathrm{NaCl}$ may be calculated in sodalite and nepheline-bearing rocks and constrained in undersaturated rocks that do not contain sodalite. Available thermodynamic data were combined with experimental equilibrium reversals for the reaction

$$
6 \mathrm{NaAlSiO}_{4}+2 \mathrm{NaCl}=\mathrm{Na}_{8} \mathrm{Al}_{6} \mathrm{Si}_{6} \mathrm{O}_{24} \mathrm{Cl}_{2}
$$

in order to calculate the stability field of sodalite-bearing assemblages.

Comprehensive studies of sodalite stability relations were made by Wellman, who determined the decomposition temperatures of sodalite at low $\mathrm{NaCl}$ fugacities (WELLMAN, 1969a,b) and in dilute aqueous solutions (WELLMAN, 1970a). WELLMAN (1970b) also derived activity coefficients for $\mathrm{NaCl}$ in aqueous solution at elevated temperatures and pressures from his experiments. STORMER and CARMICHAEL (1971) used the decomposition data of WELLMAN ( 1969b) to derive free energy data for sodalitc at elevated temperatures. BARKER (1976) evaluated the relations between sodalite and analcime as a function of temperature and salinity, and BINSTED 
(1981b) determined the breakdown temperature of sodalite at various pressures, as well as the liquidus relations in the system $\mathrm{NaAlSiO}_{4}-\mathrm{SiO}_{2}-\mathrm{NaCl}-\mathrm{H}_{2} \mathrm{O}$ at 1 kbar (BINSTED, 1981a). In this study the first reversed experiments of reaction (1) at elevated pressure are reported and a thermodynamically consistent set of data are derived for the phases in the system $\mathrm{NaAlSiO}_{4}-\mathrm{NaCl}$.

\section{NOMENCLATURE AND SUMMARY OF PHASES IN THE SYSTEM $\mathrm{NaAISiO}_{4}-\mathrm{NaCl}$}

Sodalite is the only known polymorph of $\mathrm{Na}_{8} \mathrm{Al}_{6} \mathrm{Si}_{6} \mathrm{O}_{24} \mathrm{Cl}_{2}$, although HAZEN and SHARP (1988) observed crystal deterioration above $30 \mathrm{kbar}(298 \mathrm{~K}$ ) which may be due to a reconstructive transition to a high-pressure form. Halite $(\mathrm{NaCl}(s)$, liquid $\mathrm{NaCl}(\mathrm{NaCl}(l)$ and $\mathrm{NaCl}(v)$ are the phases of $\mathrm{NaCl}$ considered in this study. There are at least six known phases of $\mathrm{NaAlSiO}_{4}$. These include several high-pressure phases, three nepheline polymorphs and two carnegieite polymorphs. KELLEY et al. (1953) defined the nepheline polymorphs as $\delta$-nephelite (298-467 K), $\beta$-nephelite (467$1180 \mathrm{~K}$ ) and $\gamma$-nephelite ( $1180-1525 \mathrm{~K}$ ). ROBIE et al. (1978) defined the $467 \mathrm{~K}$ transition as the $\alpha-\beta$ transition. In this paper, the three phases (with increasing temperature) are $\alpha$ $\beta$ - and $\gamma$-nepheline. The two carnegieite polymorphs have been defined by KELLEY et al. (1953) as the $\delta$-carnegieite $(298-980 \mathrm{~K})$ and $\beta$-carnegieite $(980-1700 \mathrm{~K})$. For consistency, the low- and high-temperature polymorphs of carnegieite are defined as $\alpha$-carnegieite and $\beta$-carnegieite, respectively.

\section{EXPERIMENTAL PROCEDURE}

\section{Starting materials}

The sodalite used for all experiments was collected from a sodalitesyenite body exposed in the DeMix quarry, Mont St-Hilaire, Quebec (CURRIE et al., 1986). Its composition was determined with an automated Cameca CAMEBAX microprobe at the University of Michigan (Table 1). Because feldspathoids are especially prone to beam damage (e.g., BrousSE et al., 1969; AUTEFAGE, 1980), operating conditions were carefully chosen to minimize volatilization. The degree of volatilization of sodium in halite, sodalite and nepheline was

\begin{tabular}{|c|c|c|c|c|c|c|}
\hline & $\begin{array}{l}\text { sod } \\
\text { MSH }\end{array}$ & $\begin{array}{c}\text { sod } \\
\text { PC. } 15\end{array}$ & & $\begin{array}{l}\text { sod } \\
\text { Lov }\end{array}$ & $\begin{array}{c}n e \\
\mathrm{PC}-7\end{array}$ & $\begin{array}{c}\text { ne } \\
\mathrm{PC}-17\end{array}$ \\
\hline 10 & & 37.62 & 36.50 & 36.99 & 43.27 & 43.39 \\
\hline $\mathrm{Al}_{2} \mathrm{O}_{3}$ & & 32.9 & 31. & 31.77 & 35.99 & 36.22 \\
\hline $\mathrm{Fe}_{2} \mathrm{O}_{3}$ & 0.2 & n. & & 0.17 & n.d. & n.d. \\
\hline & n.o & & & 0.05 & A. & n. \\
\hline $\mathrm{Na}_{2} \mathrm{O}$ & 24.73 & 25.6 & 26.30 & 25.84 & 21.45 & 21.50 \\
\hline $\mathrm{K}_{2} \mathrm{O}$ & 0.10 & 0.0 & 0.18 & 0.16 & 0.00 & 0.0 \\
\hline $\mathrm{Cl}_{2}$ & 6.8 & 7. & & & 0.06 & 0.2 \\
\hline$s_{2}{ }^{4}$ & 0.08 & n. & n. & 0.39 & n. & n.d \\
\hline $.0-\mathrm{Cl}, \mathrm{S}$ & 1.5 & & & 1.65 & 0.01 & 0.0 \\
\hline Total & 99.06 & 101.07 & 100.60 & 100.16 & 100.75 & 101.26 \\
\hline Si & & & & & & \\
\hline Al & & 6.10 & & 6.03 & 0.99 & 0.9 \\
\hline $\mathrm{Fe}^{3+}$ & & & & & & n. \\
\hline $\mathrm{Ca}$ & & & & 0.01 & & n.d \\
\hline & & & & & & 0.9 \\
\hline K & 0.0 & & & & & 0.0 \\
\hline $\mathrm{Cl}$ & & & & 1.76 & 0.00 & 0.01 \\
\hline $\mathrm{s}$ & & & & & & n.d. \\
\hline 0 & 23.90 & 23.82 & 24.15 & 24.02 & 3.99 & 3.99 \\
\hline
\end{tabular}

\begin{tabular}{|c|c|c|c|c|c|c|c|}
\hline \multicolumn{3}{|c|}{$\begin{array}{l}\text { sodalite, MSH } \\
\text { a- } 8.87916\end{array}$} & \multirow[b]{2}{*}{1} & \multicolumn{2}{|c|}{$\begin{array}{l}\text { sodalite }(1644 \\
1-8.8839(9)\end{array}$} & \multicolumn{2}{|c|}{$4 \mathrm{~K}$. har: } \\
\hline riki & drobs & $d($ calc $)$ & & tikl & $\mathrm{d}$ (obs) & drcali: & 3 \\
\hline 1.10 & F. 28 & 6.28 & 100 & 110 & 6.30 & 6.28 & 4 \\
\hline 200 & 4.48 & 4.44 & ? & 200 & 4.45 & 4.4 & 9 \\
\hline 210 & 3.98 & 3.97 & ! & 11 & 3.63 & 3.63 & 1.00 \\
\hline 211 & 3.62 & 3.62 & $1 \%$ & 222 & 2.564 & $2.56 \%$ & 15 \\
\hline 222 & 2.564 & 2.563 & is & 321 & 2.375 & 2.314 & $l^{i j}$ \\
\hline 321 & 2.373 & 2.373 & $?$ & 330 & 2.094 & $20 \%$ & 20 \\
\hline 400 & 2.218 & 2.220 & 1 & 422 & 1.813 & $1.87 ?$ & $?$ \\
\hline 330 & 2.094 & 2.093 & $\theta$ & 440 & 1.570 & 1.70 & $\therefore$ \\
\hline 420 & 1.986 & 1.985 & 3 & 600 & 1.480 & $1,4:$ & 3 \\
\hline 422 & L. 813 & 1.812 & 1 & 611 & 1.442 & $1 . t_{t} / 4 \mathrm{j}$ & 2 \\
\hline 510 & 1.742 & 1. 741 & 2 & $5,4 i$ & 1.371 & $1.31 \%$ & $\therefore$ \\
\hline 521 & 1. 621 & 1.021 & 1 & 5.22 & 1.339 & 1.314 & 3 \\
\hline 440 & 1.570 & 1.570 & $\because$ & $\geqslant 1$ & 1209 & 1.204 & $\because$ \\
\hline 600 & 1. 480 & 1.480 & 8 & & & & \\
\hline 611 & $1,4: 40$ & 1.440 & 3 & & & & \\
\hline 541 & 3370 & 1.370 & $!$ & & & & \\
\hline $\begin{array}{l}622 \\
721\end{array}$ & $\begin{array}{l}1.339 \\
1.208\end{array}$ & $\begin{array}{l}1.339 \\
1.208\end{array}$ & $\frac{1}{1}$ & & & & \\
\hline \multicolumn{4}{|c|}{$\begin{array}{l}\text { sodalite }(1173 \mathrm{~K}, 8.4 \mathrm{kbar}) \\
a=8.879(2)\end{array}$} & \multicolumn{4}{|c|}{$\begin{array}{l}\text { nepheline }(1273 \mathrm{~K}, 10 \mathrm{kbar} \\
\mathrm{a}=9.972(1), c=8.333(1)\end{array}$} \\
\hline hk? & a(abs) & $d(c a l c)$ & I & hk 1 & $d$ (obs) & d(cale) & I \\
\hline 110 & 6.29 & 6.28 & 73 & & 4.17 & 4.17 & 90 \\
\hline 211 & 3.63 & 3.63 & 100 & 201 & 3.83 & 3.63 & 100 \\
\hline 222 & 2.5655 & 2.563 & 15 & 211 & 3.039 & 3.039 & 5 \\
\hline 321 & 2.334 & 2.373 & 14 & 202 & 2,998 & 2,998 & 95 \\
\hline 330 & 2.092 & 2.093 & 16 & 300 & 2.878 & 2.879 & 15 \\
\hline fon & 1.480 & 1.1180 & 3 & 212 & 2.569 & 2.576 & 10 \\
\hline & & & & 220 & 2.493 & 2,443 & b \\
\hline & & & & 203 & 2.336 & 2.336 & 20 \\
\hline & & & & 213 & 2.116 & $2.1 \ldots$ & 1.0 \\
\hline \multicolumn{4}{|c|}{$\begin{array}{l}\text { nepheline }(1373 \mathrm{k}, 1 \mathrm{bar}) \\
\mathrm{a}=9.985(2), \mathrm{c}-8.322(2)\end{array}$} & \multicolumn{4}{|c|}{$\begin{array}{l}\text { nepheline }(1073 \mathrm{k}, 8 \text { kbar }) \\
\mathrm{a}-9.978(2), \mathrm{c}-8.332(2)\end{array}$} \\
\hline hal & $d(a b s)$ & $d(c a l c)$ & I & hk1 & $d$ (obs) & $d(c a l c)$ & I \\
\hline 002 & 4.16 & 4.16 & 75 & 02 & 4.17 & 4.17 & 65 \\
\hline 201 & 3.83 & 3.84 & 100 & & 3.84 & 3.84 & 95 \\
\hline 202 & 2.998 & 2.998 & 100 & 2.11 & 3.042 & 3.041 & 5 \\
\hline 300 & 2.882 & 2.882 & 15 & & 2.999 & 2.999 & 100 \\
\hline 203 & 2.335 & 2.335 & 20 & & 2.880 & 2.880 & 30 \\
\hline 311 & 2.305 & 2.305 & 10 & 203 & 2.336 & 2.336 & 35 \\
\hline 310 & 2. 399 & 2.398 & 10 & 213 & 2.115 & 2.116 & 10 \\
\hline
\end{tabular}

evaluated at various operating conditions. Short $(2 \mathrm{sec})$ successive counting periods were made on a single rastered area for an extended time period. For the operating conditions of $5 \mathrm{kV}$ accelerating voltage, $5 \mathrm{nA}$ beam current, with a beam rastered over $3 \mu \mathrm{m}^{2}$, there was no detectable sodium loss. These operating conditions were used to analyze for $\mathrm{Na}, \mathrm{Al}, \mathrm{Si}, \mathrm{S}$ and $\mathrm{Cl}$; operating conditions were increased to $12 \mathrm{kV}$ and $12 \mathrm{nA}$ for analysis of $\mathrm{K}$ and Fe. The sodium content of sodalite is greater than that of any other aluminosilicate, so halite was used as a standard for both sodium and chlorine. The other standards employed were andalusite for $\mathrm{Al}$, albite for $\mathrm{Si}$, potassium feldspar for $\mathrm{K}$, acmite for $\mathrm{Fe}$ and anhydrite for $\mathrm{S}$. Because of the low accelerating voltage and the dominance of light elements, it was critical to carbon-coat samples and standards simultaneously. The composition of sodalite determined in this study is in agreement with a previous analysis (PETERSON, 1983) of sodalite from the same locality. Nevertheless, the calculated site vacancies (Table 1) have a high uncertainty due to the susceptibility of sodalite to beam damage. Previous sodalite analyses with the electron microprobe also require a large vacancy contribution, presumably as a result of volatilization of sodium and chlorine (e.g., AUTEFAGE, 1980). In contrast, wet chemical analyses of sodalite (USSING, 1912; VLASOV et al., 1966; Table 1) do not require any vacancy contributions. For the purposes of phase equilibrium calculations, site vacancies were considered to be artifacts of the analytical technique and were ignored.

The degree of Al-Si disorder of the Mont St-Hilaire sodalite and sodalite synthesized at $8 \mathrm{kbar}$ and $1173 \mathrm{~K}$ was evaluated by D. A. Howell at the University of Illinois using ${ }^{29} \mathrm{Si}$ nuclear magnetic resonance spectroscopy. Neither the natural nor synthetic sodalite show any evidence of Al-Si disorder.

Cell dimensions for selected sodalites and nephelines of this study were determined by J. E. Post at the Smithsonian Institution, with a smear mount on a quartz plate using an automated Scintag powder diffractometer with $\mathrm{Cu}-\mathrm{K} \alpha$ radiation. The measurements were made at $1^{\circ} 2 \theta / \mathrm{min}$ with an internal silicon standard (NBS 640-a). All data were processed with a least-squares lattice refinement program based on a minimum of six reflections (Table 2 ). The calculated cell parameters of the Mont St-Hilaire sodalite are nearly identical to those 
of Peterson (1983) [ $a=8.877(2)]$ for sodalite from the same locality.

Nepheline was synthesized by decomposing the Mont St-Hilaire sodalite in a platinum crucible at $1623 \mathrm{~K}$ for 7 hours, followed by annealing at $1373 \mathrm{~K}$ for 13 hours and by reacting sodalite to nepheline $+\mathrm{NaCl}(s)$ in a sealed platinum capsule at $1323 \mathrm{~K}$ and $20 \mathrm{kbar}$ confining pressure. The nepheline synthesized at 1 bar has a slightly greater volume than the nepheline synthesized at high pressure (Table 2). The dependence of nepheline cell parameters on its thermal history has been observed previously (SMITH and TUTTLE, 1957; DONNAY et al., 1959; HENDERSON and ROUX, 1976, 1977). After a highpressure experiment, the cell parameters of nepheline are independent of the initial synthesis technique of the nepheline starting material. For most experiments the nepheline prepared by decomposing sodalite at $1 \mathrm{~atm}$ was used. The $\mathrm{NaCl}$ used in the experiments was Fisher Reagent Grade.

\section{Experimental method}

The stability of sodalite as defined by reaction (1) was determined at 1 bar and at elevated pressures. Equal masses of sodalite and nepheline with excess $\mathrm{NaCl}$ were loaded into platinum sample capsules, dried at $383 \mathrm{~K}$ for 30 minutes and promptly sealed. The excess $\mathrm{NaCl}$ was added to all sample runs to insure that $a(\mathrm{NaCl})=1$. Starting materials and experimental products were examined optically as well as by X-ray diffraction and microprobe (Tables 1 and 2). A variation of $30 \%$ or more in the integrated intensities in the X-ray patterns of sodalite or nepheline comprised a half reversal. Most reactions went to completion.

One-atmosphere experiments were conducted in a platinum-wound vertical quench furnace at the Geophysical Laboratory. The sample capsules were hung adjacent to a $\mathrm{Pt}_{100}-\mathrm{Pt}_{90} \mathrm{Rh}_{10}$ thermocouple monitored by a Newport digital thermometer and suspended vertically in the furnace. All samples were drop-quenched into water. Variations in temperature were less than $\pm 3^{\circ} \mathrm{C}$ at the thermocouple junction; the thermocouple was calibrated bascd on the melting point of gold $(1336.15 \mathrm{~K})$. A total of 22 runs were made.

The high-pressure experiments were conducted in the piston/cylinder apparatus of SRB at Stony Brook and later at the USGS, Menlo Park, with a $2.54 \mathrm{~cm}$ diameter $\mathrm{NaCl}$-graphite furnace based on the design of JOHANNES (1978) as modified by BOHLEN (1984). All experiments were conducted with the "hot piston-in" method (MIRWALD et al., 1975; JOHANNES, 1978; BOHLEN, 1984). Temperatures were measured with a $\mathrm{Pt}_{100}-\mathrm{Pt}_{90} \mathrm{Rh}_{10}$ thermocouple abutting the platinum sample capsule and were monitored by a room-temperature compensated digital thermometer. No correction was made for effects of pressure on the thermocouple. Temperature variations were less than $\pm 3^{\circ} \mathrm{C}$, and absolute temperature variations across the platinum capsule were less than $\pm 5^{\circ} \mathrm{C}$ (BOHLEN, 1984). Pressures were measured with a digital Heise gauge; variations were less than $0.1 \mathrm{kbar}$. A total of 29 runs were made.

\section{EXPERIMENTAL RESULTS}

\section{One atmosphere}

The 1 atm breakdown temperature of sodalite to carnegieite (the high-temperature $\mathrm{NaAlSiO}_{4}$ polymorph) and $\mathrm{NaCl}$ (liquid) was reversed between 1649-1652 K (Table 3). These data are in good agreement with the experimental determinations of WELLMAN (1969a) (1657-1667 K) and DEMIDENKO et al. (1983) (>1623 K), but far higher than those of TOMISAKA and EUGSTER (1968) (1503 $\pm 5 \mathrm{~K}$ ).

\section{High pressure}

The breakdown of sodalite to $\beta$-nepheline and halite (reaction [1]) was reversed at $923 . \mathrm{K}(7.6-8.0 \mathrm{kbar}), 973 \mathrm{~K}$ (7.4-7.6 kbar), $1073 \mathrm{~K}$ (7.8-8.0 kbar) and $1173 \mathrm{~K}(8.4-8.6$ kbar) (Table 3). Reaction rates at all temperatures were relatively rapid, even though all runs were anhydrous. The $\mathrm{NaCl}$

\begin{tabular}{|c|c|c|c|c|c|}
\hline Expt \# & $\begin{array}{l}\text { Temp } \\
(\mathrm{K})\end{array}$ & $\begin{array}{l}\text { Pressure } \\
\text { (kbar) }\end{array}$ & $\begin{array}{l}\text { Duracion } \\
\text { (hrs) }\end{array}$ & $\begin{array}{l}\text { Starting } \\
\text { materials }\end{array}$ & Resules \\
\hline vQ -3 & 1644 & 0.001 & 3 & sod, $\mathrm{cg}, \mathrm{NaCl}$ & sod, $\mathrm{NaCl}$ \\
\hline VQ-5 & 1649 & 0.001 & 6 & sod, $\mathrm{Cg}, \mathrm{MaCl}$ & sod, $\mathrm{NaCl}$ \\
\hline VQ-6 & 1652 & 0.001 & 12 & sod, $\mathrm{Cg}, \mathrm{NaCl}$ & $\mathrm{cg}, \mathrm{NaCl}$ \\
\hline PC- 964 & 923 & 7.6 & 185 & sod, ne, $\mathrm{NaCl}$ & $\begin{array}{r}\text { sod, } \mathrm{NaCl} \\
\text { trace ne }\end{array}$ \\
\hline$P C=971$ & 923 & 8.0 & 120 & sod, ne, $\mathrm{NaCl}$ & $\begin{array}{l}\text { ne, NaCl } \\
\text { minor sod }\end{array}$ \\
\hline$P C-26$ & 973 & 7.4 & 144 & sod, ne, $\mathrm{NaCl}$ & sod, $\mathrm{NaCl}$ \\
\hline PC. & 973 & 7.6 & 144 & sod, ne, $\mathrm{NaCl}$ & ne, NaCl \\
\hline PG-11 & 1073 & 7.8 & 41 & sod, ne, $\mathrm{NaCl}$ & sod, $\mathrm{NaCl}$ \\
\hline PC- 8 & 1073 & 8.0 & 22 & sod, ne, $\mathrm{NaCl}$ & $\begin{array}{l}\text { ne, } \mathrm{NaCl} \\
\text { trace sod }\end{array}$ \\
\hline PC- 15 & 1173 & 8.0 & 21 & sod, ne, $\mathrm{NaCl}$ & sod, $\mathrm{NaCl}$ \\
\hline $\mathrm{PC}-16$ & 1173 & 8.4 & 23 & sod, ne, $\mathrm{NaCl}$ & $\begin{array}{r}\text { sod, } \mathrm{NaCl} \\
\text { trace ne }\end{array}$ \\
\hline PC -17 & 1173 & 8.6 & 23 & sod, ne, $\mathrm{NaCl}$ & $\begin{array}{l}\text { ne, } \mathrm{NaCl} \\
\text { trace sod }\end{array}$ \\
\hline $\mathrm{PC}-7$ & 1173 & 10.0 & 22 & sod, ne, NaCl & ne, $\mathrm{NaCl}$ \\
\hline
\end{tabular}

appears to act as a flux (as well as a reactant) to drive the reaction to completion. These reversals can be fit with a univariant line with a $d P / d T$ of +5 bar $/ \mathrm{K}$ over the temperature interval 973-1173 K. However, the $923 \mathrm{~K}$ reversal requires a $d P / d T$ of $-6 \pm 6 \mathrm{bar} / \mathrm{K}$ between $973 \mathrm{~K}$ and $923 \mathrm{~K}$.

\section{THERMODYNAMIC DATA IN THE SYSTEM NaAlSiO 4 -NaCl}

Phases in the system $\mathrm{NaAlSiO}_{4}-\mathrm{NaCl}$ include $\mathrm{NaAlSiO}_{4}$ polymorphs, halite, liquid $\mathrm{NaCl}$ and sodalite. In order to calculate the complete phase diagram for this system, accurate values of entropy $\left(S_{298}^{0}\right.$ and $\left.S_{T}^{0}\right)$, volume $\left(V_{298}^{0}\right)$, thermal expansion, compressibility and free energy are needed.

\section{$\mathrm{NaCl}$}

All of the necessary thermodynamic properties are available for $\mathrm{NaCl}(s)$ and $\mathrm{NaCl}(l)$ except for the compressibility of $\mathrm{NaCl}(l)$. The compressibility coefficients ( $m$ and $n$ in Eqn. (4) for $\mathrm{NaCl}(l)$ were adjusted to fit the high-pressure experiments on the melting of $\mathrm{NaCl}$ (CLARK, 1959; BOHLEN, 1984) based on the following set of equations:

$$
-\Delta G_{298}^{1 \text { bar }}=\int_{1 \text { bar }}^{P} \Delta V d P-\int_{298}^{T} \Delta S d T
$$

where

$$
V(P, T)=V_{298}^{0}[1+A(T)][1+B(P)] .
$$

The functions $A$ and $B$ are related to the expansivity $\alpha$ and compressibility $\beta$, respectively, and are represented by the following equations ( $P$ in $\mathrm{kbar} ; T$ in $\mathrm{K}$ ):

$$
B(P)=-m \cdot 10^{-3} \cdot P+n \cdot 10^{-6} \cdot P^{2}
$$

and

$$
\begin{aligned}
A(T)= & \left\{e \cdot 10^{-2}+f \cdot 10^{-3} \cdot(T-273)+g \cdot 10^{-7}\right. \\
& \left.\times(T-273)^{2}+h \cdot 10^{-10} \cdot(T-273)^{3}\right\} / 100 .
\end{aligned}
$$

All thermodynamic data are presented in Table 4.

\section{$\mathrm{NaAlSiO}_{4}$}

All thermodynamic data for the $\mathrm{NaAlSiO}_{4}$ polymorphs needed in this study have been measured, except for the low- 
Table 4. Thermodynamic data of minerals used in for caloulated tquilitiria. $\mathrm{S}$ in $J / \mathrm{mol} \cdot \mathrm{K}, \Delta \mathrm{G}$ in $\mathrm{kJ} / \mathrm{mol}, \mathrm{V}$ in $\mathrm{cm}^{3}, \mathrm{~T}$ in $\mathrm{K}, \mathrm{P}$ in $\mathrm{kbar}$

\begin{tabular}{|c|c|c|c|c|c|c|c|c|c|}
\hline & $S_{2}^{*} 98$ & ref & A & b & $c$ & d & $m t$ & $\Delta G_{29 g}^{\circ}$ & ref \\
\hline$*-c$ & 129.6 & (1) & 133.68 & 61.56 & 17.65 & -797.99 & ;? & .1958 & $1 \%$ \\
\hline$\beta-\operatorname{cg}^{2}$ & 129.6 & (1) & 178.95 & 5.37 & -7.28 & -1045.28 & a: & 1963 & $\because$ \\
\hline Nacl $(\mathrm{s})$ & 32.12 & (3) & 35.94 & 27.51 & -5.38 & .207 .92 & $3 i$ & .384 .02 & (i) \\
\hline $\mathrm{NaCl}(1)$ & 95.06 & (3) & 65.44 & 4.07 & 12.47 & -387.46 & (i) & $-365.6 ?$ & (3) \\
\hline Hacd (v) & 229.69 & (3) & 37.35 & 073 & 083 & $-214,35$ & (3) & .201 .33 & 189 \\
\hline$\beta+n e$ & 124.35 & (4) & 108.24 & 62.27 & -16.25 & -625.82 & $(4,5)$ & .1972 .5 & (5) \\
\hline$y-\pi e^{2}$ & 125.5 & (6) & 145,72 & 25.17 & 14.62 & -848.87 & (4) & $.213 \%$ & (4) \\
\hline sod & 909.8 & (7) & 909.81 & 305.49 & 92.75 & -5421.44 & (i) & $.1269 / 3$ & (a) \\
\hline
\end{tabular}

\begin{tabular}{|c|c|c|c|c|c|c|c|c|c|c|}
\hline & $v_{2 \geq 8}$ & ref & E & $\mathrm{f}$ & B & है & ref. & m & $n$ & $x \in f$ \\
\hline$x \cdot c g$ & 53.6 & (8) & .83 .84 & 6.78 & .11 .45 & 3.44 & (9) & 2.63 & 11.83 & $(10)$ \\
\hline$\beta-c g^{2}$ & 57.0 & (11) & -83.86 & 6.78 & -11.45 & 3.44 & (9) & 2.63 & 11.83 & (10) \\
\hline $\mathrm{RaCl}(\mathrm{s})$ & 27.02 & (4) & .17 .15 & 10.23 & 100.92 & -32.82 & (i3) & 4.15 & 40.54 & (14) \\
\hline $\mathrm{HACl}$ (1) & 31.6 & (15) & 188.72 & 1.7 .78 & 82.57 & 27,53 & (16) & 24.7 & 800 & $\because$ \\
\hline$\alpha \cdot n e$ & 54.18 & (17) & $-59,38$ & 2.56 & 38.06 & -14.89 & (17) & 2.06 & 4,89 & (14) \\
\hline$y-n e^{2}$ & 54.9 & (18) & 0.00 & 4.73 & 0.00 & 0.00 & (i7) & 2.06 & 4.89 & (14) \\
\hline $\operatorname{sod}$ & 421.3 & (19) & 0.33 & 1.96 & 51.08 & -15.73 & (30) & 1.76 & 0.00 & (21) \\
\hline
\end{tabular}

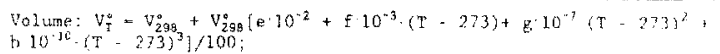

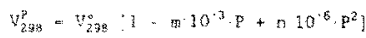

valid above $960 \mathrm{~K}$ transition: 2 valid above $1133 \mathrm{~K}$ transition

"excluting excess entropy contribution $(61.7 \mathrm{~J} / \mathrm{mol} \cdot \mathrm{K})$ below 973

Aboreyations. NaCl (s) - solid NaCl. NaCl (1) = Na"l liquid:

NaCl (v) - NaCl vapor; sod - sodalite.

1 ) Estimated, this study; 2) Kelley et al., 1953; 3) Chase et al., 1985

4. Robie et al., 1978; 5) thenderson and Thompson, 1980; G) thed value fo

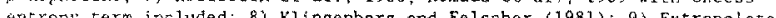

thropy ter included. 8) Kingenberg and Felscher (1981); 9) Extrapolated

high Tata of kunmel, 1949; 10) Cristobalite data from Robinson et al.

13)

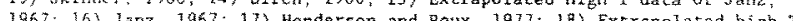

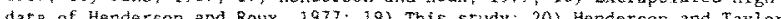

dat $\mathrm{t}$ of henderson and Roux,
1978 : 211 Hazan and Sharp, 1988

temperature heat capacity of carnegieite (stable above 1525 $\mathrm{K}$ ) and the compressibility of carnegieite and $\gamma$-nepheline (the nepheline polymorph stable above $1180 \mathrm{~K}$ and below $1525 \mathrm{~K}$; KeLLEY $e t$ al., 1953). The thermal expansion of $\gamma$ nepheline has been measured (HENDERSON and ROUX, 1976 , 1977), but only over a narrow temperature range. These thermodynamic properties were estimated in the following ways:

1. The entropy of carnegieite at $298 \mathrm{~K}$ was estimated from the following relation (FYFE et al., 1958, p. 34):

$$
\begin{aligned}
S_{298}^{0}(\mathrm{cn})=S_{298}^{0}(\mathrm{ne})+2.5 & \left(\mathrm{~J} / \mathrm{mol} \cdot \mathrm{K} \cdot \mathrm{cm}^{3}\right) \\
& \times\left[V_{298}^{0}(\mathrm{cn})-V_{298}^{0}(\mathrm{ne})\right]
\end{aligned}
$$

where $\mathrm{cn}=\alpha$-carnegieite and ne $=\alpha$-nepheline (entropy in $\mathrm{J} / \mathrm{mol} \cdot \mathrm{K})$.

2. The compressibility of $\beta$ - and $\gamma$-nepheline was assumed to be equal to that of $\alpha$-nepheline. The actual compressibilities are probably slightly greater than this estimate (COHEN and KLEMENT, 1976), but small errors in this second-order term will not significantly alter the calculated equilibria.

3. The compressibility of carnegieite was assumed to be the same as that of isostructural cristobalite.

4. The thermal expansion of $\gamma$-nepheline and carnegieite were extrapolated linearly to temperatures of $1600 \mathrm{~K}$ and $1700 \mathrm{~K}$, respectively, which may introduce small systematic errors.

\section{$\mathrm{Na}_{8} \mathrm{Al}_{6} \mathrm{Si}_{6} \mathrm{O}_{24} \mathrm{Cl}_{2}$}

The heat capacity of Mont St-Hilaire sodalite with a composition of $\mathrm{K}_{0.01} \mathrm{Na}_{7.99} \mathrm{Al}_{6.00} \mathrm{Si}_{5.96} \mathrm{Fe}_{0.04}^{3+} \mathrm{O}_{23.98} \mathrm{Cl}_{1.96}\left(\mathrm{SO}_{4}\right)_{0.02}$
(HELFFRICH et al., 1986) has been measured with low-temperature $(15-350 \mathrm{~K})$ adiabatic calorimetry and high-temperature $(298.15-1000 \mathrm{~K})$ differential scanning calorimetry (HELFFrich et al, 1986; KOMADA et al., 1989). The heat capacity of end-member sodalite $\left(\mathrm{Na}_{8} \mathrm{Al}_{6} \mathrm{Si}_{6} \mathrm{O}_{24} \mathrm{Cl}_{2}\right)$ was estimated by correcting for the effects of minor element substitution and contamination by fluid inclusions. The corrected value of $S_{298^{-}}^{0} S_{0}^{0}, 848.1 \pm 4.0 \mathrm{~J} / \mathrm{mol} \cdot \mathrm{K}$, is intermediate between earlier estimates of $814 \pm 30 \mathrm{~J} / \mathrm{mol} \cdot \mathrm{K}$ (SEMENOV et al. 1981 ) and $879 \pm 25 \mathrm{~J} / \mathrm{mol} \cdot \mathrm{K}$ (ZoLotov et al. 1982). The large uncertainty in the earlier estimates may result from those earlier heat capacity measurements being made only above $77 \mathrm{~K}$.

As a result of the high thermal stability of sodalite, data for thermal expansion and entropy of sodalite are needed to $1700 \mathrm{~K}$. Thermal expansion has only a small effect on the calculated phase relations, and graphical extrapolation of the volume $\left(V_{r}^{0}\right)$ of sodalite (measured to $1078 \mathrm{~K}$ ) to $1700 \mathrm{~K}$ should not result in significant errors. However, the effect of temperature on the entropy of sodalite will affect its calculated stability relations, and extrapolation of the entropy of sodalite over a large temperature range cannot be made without the risk of introducing serious errors. The procedure outlined below was used to extrapolate the entropy of sodalite (measured to $1000 \mathrm{~K}$ ) to $1700 \mathrm{~K}$.

As a first approximation, the entropy of a solid phase is equal to the sum of its components (e.g., FYFE et al., 1958; WOOD and Fraser, 1977; Helgeson et al., 1978). The entropy of sodalite at high temperature can be approximated from the relation

$$
S_{T}^{0}(\operatorname{sod}) \approx 6 S_{T}^{0}\left(\mathrm{NaAlSiO}_{4}\right)+2 S_{T}^{0}(\mathrm{NaCl})(s) .
$$

Because $\beta$-nepheline is stable only to $1133 \mathrm{~K}$ at 1 bar, entropy data above this temperature cannot be measured at 1 bar, and the substitution of $\beta$-nepheline for Eqn. (7) is not useful for determining the entropy of sodalite above $1133 \mathrm{~K}$. Instead, the entropy of sodalite at high temperatures was estimated by substituting the entrophy values of $\gamma$-nepheline, carnegieite and a fictive $\mathrm{NaAISiO}_{4}$ component (ROBINSON and HAAS, 1983 ) into Eqn. (7). The entropy difference ( $\left.\Delta S_{\text {ealc-meas }}\right)$ is nearly linear between $500 \mathrm{~K}$ and $1000 \mathrm{~K}$ when the fictive $\mathrm{NaAlSiO}_{4}$ entropy value is used. The $\Delta S_{\text {calc-meas }}$ was linearly extrapolated to $1700 \mathrm{~K}$. The entropy of sodalite above 1000 $\mathrm{K}$ was then estimated by adding the $\Delta S_{\text {calc-meas }}$ to the sums of the entropies of fictive $\mathrm{NaAlSiO}_{4}$ and $\mathrm{NaCl}(s)$ from Eqn, (3). Entropy data for $\mathrm{NaCl}(s)$ are available to $1500 \mathrm{~K}$ (CHASE et al., 1985) and were extrapolated graphically to $1700 \mathrm{~K}$ in order to make the above calculation. The uncertainty in the entropy of sodalite at $1700 \mathrm{~K}$ is estimated to be less than $2 \%$.

\section{SELECTED PHASE EQUILIBRIA IN THE SYSTEM NaAISiO $4-\mathrm{SiO}_{2}-\mathrm{NaCl}$}

\section{$\mathrm{NaCl}$}

Melting relations for $\mathrm{NaCl}$ have been well constrained as a function of pressure and temperature (CLARK, 1959; BOHLEN, 1984). The calculated melting equilibria from the data in Table 4 reproduce the melting experiments (Fig. 1a,b), because the compressibility of $\mathrm{NaCl}$ liquid was obtained from 

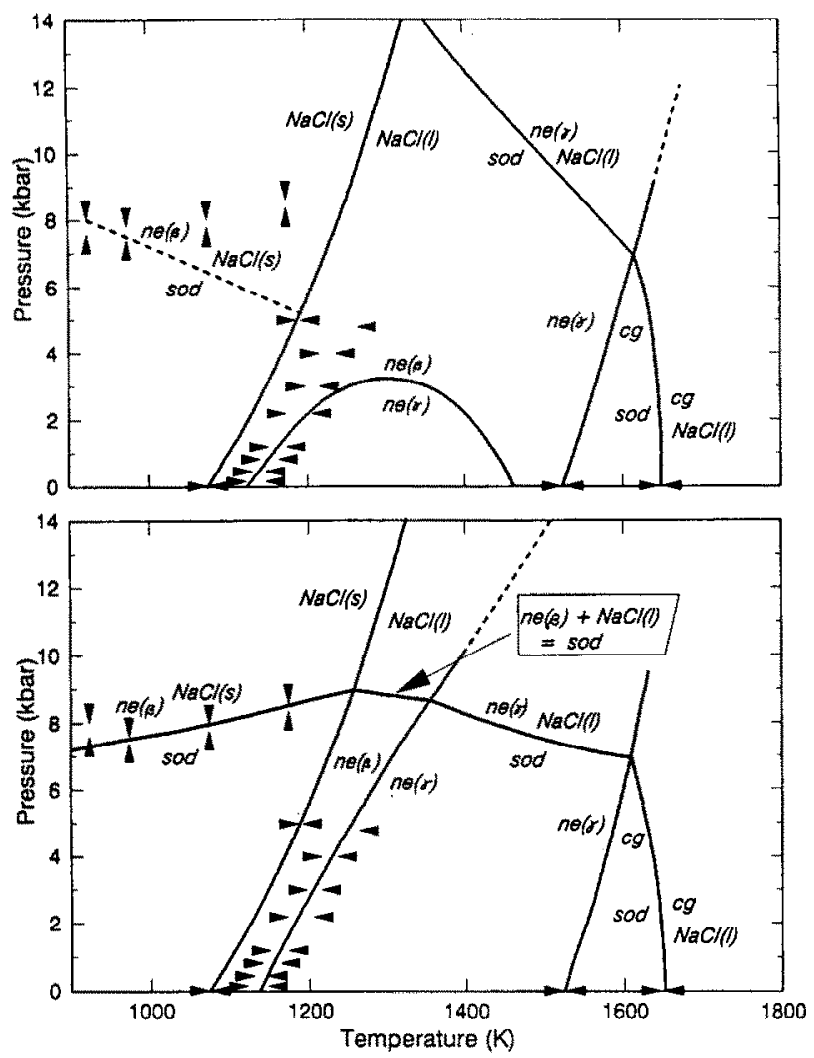

Fio. 1. Selected stability relations of phases in the system $\mathrm{NaAlSiO}_{4}-$ $\mathrm{SiO}_{2}-\mathrm{NaCl}$. Reversals (triangles) as follows: ne $(\beta)+\mathrm{NaCl}(s)=$ sod (this study); ne $(\beta)=\mathrm{ne}(\gamma)(\mathrm{COHEN}$ and KLEMENT, 1976); $\mathrm{NaCl}$ $(s)=\mathrm{NaCl}(l)$ (BOHLEN, 1984); ne $(\gamma)=\mathrm{cg}$ (BOWEN, 1912; KELLEY et al, 1953; SMTTH and TUTTLE, 1957); sod $=\mathrm{cg}+\mathrm{NaCl}(l)$ (this study; at 1649-1652 K). (Abbreviations: $\mathrm{cg}=$ carnegieite, ne $=$ nepheline, sod $=$ sodalite). Figure la is generated with the measured $S_{298}^{0}$ of sodalite. The sodalite-bearing reactions are constrained by the 1 bar, 1649-1652 K reversal except for the dashed line for reaction (9), which is fit to the 923 and $973 \mathrm{~K}$, high-pressure reversal. $\Lambda$ phase diagram cannot be generated that is consistent with both sets of experiments. Figure $1 \mathrm{~b}$ includes an excess entropy term for sodalite of $61.7 \mathrm{~J} / \mathrm{mol} \cdot \mathrm{K}$. The generated curves coincide with all experiments above $973 \mathrm{~K}$. The excess entropy contribution is only required above $923 \mathrm{~K}$.

the experimental curves. The boiling point of $\mathrm{NaCl}$ at 1 bar is $1791 \mathrm{~K}$ (ROBIE et al., 1978), well above the stability of sodalite. At pressures below 1 bar, $\mathrm{NaCl}(s), \mathrm{NaCl}(l)$ or $\mathrm{NaCl}(v)$ will coexist with sodalite (e.g., WELLMAN, 1969b). The stability fields of $\mathrm{NaCl}(s), \mathrm{NaCl}(l)$ and $\mathrm{NaCl}(v)$ at reduced $\mathrm{NaCl}$ fugacities (Fig. 2a,b) were calculated from the data in Table 4.

\section{$\mathrm{NaAlSiO}_{4}$}

$\mathrm{NaAlSiO}_{4}$ is a complex phase with at least six polymorphs. The stabilities and structural transformations of these polymorphs have received considerable attention (BOWEN, 1912; BOWEN and GREIG, 1925; KeLleX et al., 1953; SMITH and TUTTLE, 1957; TUTTLE and SMITH, 1958; DONNAY et al., 1959; ROY and ROY, 1969; COHEN and KLEMENT, 1976; HENDERSON and ROUX, 1977; HENDERSON and THOMPSON, 1980). The low-temperature polymorph of $\mathrm{NaAlSiO}_{4}$ un- dergoes two known inversions at 1 bar. The high-temperature polymorph, carnegieite, has a metastable transition in the stability field of nepheline. Additional polymorphism has been proposed at ultra-high pressures (synthesized at 180 kbar and $1273 \mathrm{~K}$, LIU, 1977; $58 \mathrm{kbar}$ and $1673 \mathrm{~K}$, SHANNON and BERZINS, 1979), and possibly at moderate temperature and pressure (443 K, 2-3 kbar, COHEN and KLEMENT, 1976).

The lowest temperature transition in nepheline $(\alpha-\beta)$ is second or higher order (MCCONNELL, 1981), and occurs over a temperature range of at least $416-469 \mathrm{~K}$. The higher temperature nepheline inversion $(\beta-\gamma)$ is complex, and may be a combination of first- and second-order behavior. The $\beta-\gamma$ nepheline transition occurs over the temperature interval 1083-1233 K (1180 K, KELLEY et al., 1953; 1123-1173 K, TUTTlE and SMITH, 1958; $1083 \mathrm{~K}$, DonNay et al., 1959; 1148-1198 K, ROY and ROY, 1969; 1118-1145 K, COHEN and KLEMENT, 1976; 1148-1233 K, HENDERSON and ROUX, 1977). The breakdown of nepheline to carnegieite is sluggish and occurs between $1521-1525 \mathrm{~K}$. The high-temperature phase, camegieite, is quenchable, although it undergoes a


Fig. 2. Stability fields of $\mathrm{NaCl}(s), \mathrm{NaCl}(l), \mathrm{NaCl}(v)$ and sodalite at various $\mathrm{NaCl}$ fugacities. Experiments of WELLMAN (1969b) are for reaction (19). The location of the sodalite stability curves is based on the reversal from this study $(1649-1652 \mathrm{~K})$ for reaction $(12)$ at the intersection with the $\mathrm{NaCl}(l)=\mathrm{NaCl}(v)$ equilibria. Dashed line is the metastable extension of sod $=\mathrm{cg}+\mathrm{NaCl}(v)$ in the nepheline stability field. Figure $2 \mathrm{a}$ is generated with the measured $S_{298}^{0}$ of sodalite; Figure $2 \mathrm{~b}$ includes an excess entropy contribution of $61.7 \mathrm{~J} /$ mol $\cdot$ K. Abbreviations as in Fig. 1. 
metastable, rapid inversion $(\alpha-\beta)$ between $944-980 \mathrm{~K}$. The temperature of this inversion depends on the thermal history of the sample (COHEN and KLEMENT, 1976). Only the $\beta-\gamma$ nepheline inversion and the $\gamma$-nepheline-carnegieite reaction directly affect the stability field of sodalite in the $P-T$ range of this study. The entropy contributions of the low-temperature nepheline inversion and the $\alpha-\beta$ carnegieite transition are included in the entropy values of the stable phases at higher temperature.

COHEN and KLEMENT ( 1976 ) determined the temperature of the $\beta-\gamma$ nepheline transition at pressures of 1 bar to $5 \mathrm{kbar}$; it occurs at approximately $1133 \mathrm{~K}$ at 1 bar and has a $d P / d T$ of $42 \mathrm{bar} / \mathrm{K}$. At temperatures up to $1200 \mathrm{~K}$ the $\beta$ - $\gamma$ transition can be fit with available thermodynamic data. With increasing temperature, the calculated $d P / d T$ decreases and eventually becomes negative, so that $\beta$-nepheline is apparently again stable at 1 bar $(\sim 1450 \mathrm{~K}$ ) (Fig. 1a). This unusual result occurs because the entropy of $\beta$-nepheline, graphically extrapolated into the $\gamma$-nepheline stability field, becomes greater than that of $\gamma$-nepheline. If the measured heat capacity and integrated entropy data for $\beta$ - and $\gamma$-nepheline are correct. then the computed stability of $\beta$-nepheline must lie both below and above that of $\gamma$-nepheline at $I$ bar. The same apparent relationship is encountered across other mixed-order phase transitions, such as $\alpha$-quartz/ $\beta$-quartz. The explanation for these unlikely stability relations is likely associated with either 1) errors in the extrapolation of the entropy of $\beta$-nepheline into the $\gamma$-nepheline stability field at $L$ bar, or 2 ) errors in the extrapolation of 1 bar entropy values to higher pressures.

The thermodynamics of second- and higher-order transitions become complex as conventional thermodynamic relationships become indeterminate (e.g. THOMPSON and PERKINS, 1981). It is possible that heat capacity contributions associated with the transition, which occur over a $100-200^{\circ} \mathrm{C}$ temperature interval below the actual transition, are being measured. If this effect is not taken into account, the $\Delta S$ associated with the phase transition will be smeared out over a large temperature interval, and will appear too small. The effects of pressure on these complex transitions is not known. but the enthalpy and entropy changes across transitions in simple salts are reduced with increasing pressure (WESTRU IM, 1974). In the present calculations, the effect of pressure on entropy is accounted for by the relationship

$$
(\partial S / \partial P)_{T}=-\alpha V,
$$

where $\alpha=$ thermal expansion. However, this expression may not adequately account for other unknown pressure effects associated with complex high-order polymorphic transitions. In this study, the $\beta-\gamma$ nepheline transition was fit by forcing the extrapolated 1 bar entropy values of $\beta$-nepheline in the $\gamma$-nepheline field to be less than those measured for $\gamma$-nepheline.

The transition temperature for the nepheline-carnegieite inversion is well documented at 1 bar but has not been determined at higher pressures. The calculated $d P / d T$ of this reaction $(70 \mathrm{bar} / \mathrm{K})$ determined with available thermodynamic data is poorly constrained because of the small $\Delta V$ and $\Delta S$ for this reaction and the uncertainties in the hightemperature thermodynamic data for $\gamma$-nepheline and carnegieite. However, a consistent set of thermodynamic data in the NaAlSiO- $\mathrm{NaCl}$ system, constrained by the nephelinecarnegieite and sodalite decomposition equilibria is generated when the $S_{298}^{0}$ of carnegieite (Table 4 ) is assumed to be 1.7 $\mathrm{J} / \mathrm{mol} \cdot \mathrm{K}(1.3 \%)$ greater than the calculated value of 127.9 $\mathrm{J} / \mathrm{mol} \cdot \mathrm{K}$ from Eqn. (6). Under these conditions the $d P /$ $d T$ for the nepheline-carnegieite transition is $72 \mathrm{bar} / \mathrm{K}$

\section{$\mathrm{NaAlSiO}_{4}-\mathrm{NaCl}$}

In order to calculate the stability of sodalite, the decomposition of sodalite by reaction (1) must be further subdivided into a series of reactions based on the stable phases for $\mathrm{NaAlSiO}_{4}$ and $\mathrm{NaCl}$. With increasing temperature, these reactions are as follows:

$$
\begin{aligned}
& 6 \mathrm{NaAlSiO}_{4}+2 \mathrm{NaCl}=\mathrm{Na}_{8} \mathrm{Al}_{6} \mathrm{Si}_{6} \mathrm{O}_{24} \mathrm{Cl}_{2} \\
& \text { nepheline }(\beta) \quad \mathrm{NaCl}(s) \quad \text { sodalite } \\
& 6 \mathrm{NaAISiO}_{4}+2 \mathrm{NaCl}=\mathrm{Na}_{8} \mathrm{Al}_{6} \mathrm{Si}_{6} \mathrm{O}_{24} \mathrm{Cl}_{2} \\
& \text { nepheline }(\beta) \quad \mathrm{NaCl}(l) \quad \text { sodalite } \\
& 6 \mathrm{NaAlSiO}_{4}+2 \mathrm{NaCl}=\mathrm{Na}_{8} \mathrm{Al}_{6} \mathrm{Si}_{6} \mathrm{O}_{24} \mathrm{Cl}_{2} \\
& \text { nepheline }(\gamma) \quad \mathrm{NaCl}(/) \quad \text { sodalite } \\
& 6 \mathrm{NaAlSiO}_{4}+2 \mathrm{NaCl}=\mathrm{Na}_{8} \mathrm{Al}_{6} \mathrm{Si}_{6} \mathrm{O}_{24} \mathrm{Cl}_{2} \text {. } \\
& \text { carnegieite } \mathrm{NaCl}(/) \quad \text { sodalite }
\end{aligned}
$$

The slope for reaction ( 9 ), calculated from the available thermodynamic data for the phases $\beta$-nepheline, $\mathrm{NaCl}(s)$ and sodalite, is $-11.0 \mathrm{bar} / \mathrm{K}$ between 973 and $1173 \mathrm{~K}$, but the slope required to fit the experimental reversals is +5 bar $/$ $\mathrm{K}$ in this temperature interval. The slope constrained by the $923 \mathrm{~K}$ and $973 \mathrm{~K}$ reversals is $6 \pm 6 \mathrm{bar} / \mathrm{K}$, consistent with the calculated slope for reaction (9). The discrepancy above $973 \mathrm{~K}$ is greater than the sum of the uncertainties in the entropy and volume data of sodalite, $\beta$-nepheline and $\mathrm{NaCl}$ $(s)$. A fit to the high-pressure experimental reversals can be obtained if the entropy of sodalite is increased by $61.7 \mathrm{~J} /$ $\mathrm{mol} \cdot \mathrm{K}(7.3 \%)$ above $973 \mathrm{~K}$. This entropy contribution could be due to configurational disorder, nonstoichiometry or a phase transition. Possible entropy contributions to nepheline or $\mathrm{NaCl}$ must be ruled out, because these adjustments would increase, rather than decrease, the misfit between calculated and experimental slopes of reaction (9).

The entropy contribution from complete configurational disorder between $\mathrm{Al}$ and $\mathrm{Si}$ over two tetrahedral sites is $12 R$ In 2 , or $69.15 \mathrm{~J} / \mathrm{mol} \cdot \mathrm{K}$, where $R=8.3143 \mathrm{~J} / \mathrm{mol} \cdot \mathrm{K}$. The predicted value of $61.7 \mathrm{~J} / \mathrm{mol} \cdot \mathrm{K}$ requires $58 \%$ disorder over 12 sites (where $100 \%=$ complete disorder). Other entropy contributions resulting from nonstoichiometry are possible, but extreme nonideality would be required to account for the large entropy contribution required to fit the experimental reversals.

Excess entropy predicted for sodalite from the experimentally determined slope of reaction (9) is not in agreement with other data on Cl-bearing sodalites. Structure refinements (LONS and Schulz, 1967; PETERSON, 1983) and infrared studies (HENDERSON and TAYLOR, 1979) of sodalite are consistent with total or near-total order of $\mathrm{Al}-\mathrm{Si}$. A ${ }^{29} \mathrm{Si}$ nuclear magnetic resonance study on the Mont St-Hilaire sodalite equilibrated at $1123 \mathrm{~K} / 6 \mathrm{kbar}$ was performed by D. A. Howell 
in the Laboratory of Dr. J. R. Kirkpatrick at the University of Illinois, Urbana, and it shows no signs of Al-Si disorder (D. Howell, pers. commun.). This natural sample was held at elevated pressure and temperature, but was not synthesized from nepheline $+\mathrm{NaCl}$. It is possible that sodalite rapidly synthesized from $\mathrm{NaCl}$ and nepheline may be disordered, as is ultramarine when pyrolitically synthesized from kaolin, sodium carbonate and sulfur (KLINOwSKI et al., 1987). Because there is a one to one ratio of tetrahedral $\mathrm{Al}$ and $\mathrm{Si}$ in sodalite, any disorder of $\mathrm{Al}-\mathrm{Si}$ would violate the "aluminum avoidance principle" (LOEWENSTEIN, 1954). Yet ultramarine, which has the sodalite structure with sulfur as the cavity anion, exhibits total Al-Si disorder (KLINOWSKI et al., 1987), iodine sodalite $\left(\mathrm{Na}_{8}\left(\mathrm{Al}_{6} \mathrm{Si}_{6} \mathrm{O}_{24}\right) \mathrm{I}_{2}\right)$ appears to have partial Al-Si disorder (BEAGLEY et al., 1982) and there is some suggestion of disorder in synthetic Rb-rich sodalite above 973 K (HASSAN and GRUNDY, 1984). Al-Si disorder could be responsible for the experimentally determined $d P / d T$ for reaction (9) above $973 \mathrm{~K}$ as well. The cell parameters of sodalite quenched from high temperatures are greater than the natural material (Table 2), consistent with this hypothesis. Moreover, the onset of disordering, $\sim 973 \mathrm{~K}$, roughly agrees with the temperatures at which GoLDSMITH and JENKINS (1985) found Al-Si redistribution associated with the low- to highalbite transition $(930 \mathrm{~K}$ ). This transition, which involves AlSi diffusion between vertex-connected tetrahedra, is facilitated by pressure, which may account for the lack of calorimctric evidence for the transition below $1000 \mathrm{~K}$, the limit of the calorimetric data.

An alternative explanation for the discrepancy between the experimentally and thermodynamically determined stability fields for sodalite-bearing assemblages is that sodalite undergoes a reversible phase transition at elevated pressure and temperature. If this is the case, and the thermodynamic properties of this new phase are sufficiently different from sodalite, a consistent fit of the thermodynamic data to the reversals could be made without requiring configurational disorder.

The calculated stability relations of sodalite-bearing assemblages generated by an internally consistent set of thermodynamic data must pass through the reversals for Eqns. (9) and (12). It is not possible to derive a phase diagram for the system $\mathrm{NaAlSiO}_{4}-\mathrm{NaCl}$ (Fig. la) using the measured thermodynamic database that is consistent with the experimental reversals from this study. However, agreement can be achieved if the entropy of sodalite above $923 \mathrm{~K}$ is increased by $61.7 \mathrm{~J} / \mathrm{mol} \cdot \mathrm{K}$ and the $S_{298}^{0}$ of carnegieite is $1.7 \mathrm{~J} / \mathrm{mol} \cdot \mathrm{K}$ greater than the estimate from Eqn. (6) (Fig. 1b).

\section{Aluminosilicate solid-solution in $\mathrm{NaCl}$ liquid}

The experimentally determined $\mathrm{NaCl}(l)$-bearing univariant equilibria will differ from the calculated ones if $\mathrm{NaCl}(l)$ is significantly diluted by solid-solution with dissolved aluminosilicate. In order to determine the degree of solid-solution of aluminum and silicon in $\mathrm{NaCl}(l)$, large sodalite crystals were equilibrated with $\mathrm{NaCl}$ at $1621 \mathrm{~K}$ for 19 hours in a scaled platinum capsule. The sample was quenched, the sodalite crystals were removed, and the salt was analyzed for $\mathrm{Al}$ and $\mathrm{Si}$ with the Jobin Yvon JY70 Type II inductively coupled plasma-atomic emission spectrometer at the Geophysical Laboratory. Silicon is undetectable and aluminum has a concentration of $<30 \mathrm{ppm}$. The effects of these small concentrations of $\mathrm{Al}$ and $\mathrm{Si}$ in $\mathrm{NaCl}$ on the calculated phase equilibria may be ignored.

\section{$\mathrm{NaAlSiO}_{4}-\mathrm{SiO}_{2}-\mathrm{NaCl}$}

Expanding the $\mathrm{NaAlSiO}_{4}-\mathrm{NaCl}$ system to include $\mathrm{SiO}_{2}$ adds the phases jadeite, albite and quartz along the $\mathrm{NaAlSiO}_{4}-$ $\mathrm{SiO}_{2}$ join. The formation of jadeite (NEWTON and KENNEDY, 1968; BOETTCHER and WYLLIE, 1968) by the equilibrium

$$
\begin{array}{cc}
2 \mathrm{NaAlSi}_{2} \mathrm{O}_{6} & =\mathrm{NaAlSiO}_{4} \\
\text { jadeite } & \text { nepheline } \\
\mathrm{NaAlSi}_{3} \mathrm{O}_{8} & \text { albite }
\end{array}
$$

can be combined with equilibrium (9) to generate

$$
\begin{array}{ll}
12 \mathrm{NaAlSi}_{2} \mathrm{O}_{6}+ & 2 \mathrm{NaCl} \\
\text { jadeite } & \text { halite } \\
= & \mathrm{Na}_{8} \mathrm{Al}_{6} \mathrm{Si}_{6} \mathrm{O}_{24} \mathrm{Cl}_{2}+6 \mathrm{NaAlSi}_{3} \mathrm{O}_{8} .
\end{array}
$$

The formation of albite (HAYS and BELL, 1973) by the reaction

$$
\begin{array}{ccc}
\mathrm{NaAlSi}_{3} \mathrm{O}_{8} & =\underset{\mathrm{NaAlSi}}{2} \mathrm{O}_{6} & +\mathrm{SiO}_{2} \\
\text { albite } & \text { jadcite } & \text { quartz }
\end{array}
$$

can be combined with equilibrium (14) to generate two quartz-sodalite bearing reactions:

$$
\begin{aligned}
& 6 \mathrm{NaAlSi}_{2} \mathrm{O}_{6}+2 \mathrm{NaCl}=\mathrm{Na}_{8} \mathrm{Al}_{6} \mathrm{Si}_{6} \mathrm{O}_{24} \mathrm{Cl}_{2}+6 \mathrm{SiO}_{2} \text { (16) } \\
& \text { jadeite halite sodalite quartz }
\end{aligned}
$$

and

$$
\begin{aligned}
& 6 \mathrm{NaAlSi}_{3} \mathrm{O}_{8}+2 \mathrm{NaCl}=\mathrm{Na}_{8} \mathrm{Al}_{6} \mathrm{Si}_{6} \mathrm{O}_{24} \mathrm{Cl}_{2}+12 \mathrm{SiO}_{2} \text { (17) } \\
& \text { albite halite sodalite quartz. }
\end{aligned}
$$

The pressure and temperature at which reactions (9) and (13) intersect is dependent on the presumed high-pressure/ temperature entropy of sodalite. If the slope of reaction (9) changes from $+5 \mathrm{bar} / \mathrm{K}$ to $-11 \mathrm{bar} / \mathrm{K}$ between 973 and 923 $K$, then the invariant point defined by reaction (9) and (13) occurs at $773 \mathrm{~K}$ and $10 \mathrm{kbar}$. If the excess entropy contribution to sodalite is included down to $298 \mathrm{~K}$, the invariant point defined by reactions (9) and (13) occurs at $573 \mathrm{~K}$ and 5.5 kbar. In either case, the mutual stability of sodalite and jadeite will be reduced further if $\mathrm{NaCl}$ activity is less than 1 . The stability field of quartz + sodalite, limited by reactions (16) and (17), lies at temperatures below $298 \mathrm{~K}$. The equilibrium coexistence of natural sodalite and quartz or sodalite and jadeite has never been reported to our knowledge.

\section{Comparison with previous work}

WELlMAN (1969b) determined the decomposition temperature of sodalite to $\gamma$-nepheline $+\mathrm{NaCl}(v)$. The data are shown in Fig. $2 \mathrm{a}$ and $\mathrm{b}$ along with the calculated equilibrium for the breakdown of sodalite by the equilibria

$$
\begin{aligned}
& 6 \mathrm{NaAlSiO}_{4}+2 \mathrm{NaCl}=\mathrm{Na}_{8} \mathrm{Al}_{6} \mathrm{Si}_{6} \mathrm{O}_{24} \mathrm{Cl}_{2} \\
& \gamma \text {-nepheline } \mathrm{NaCl}(v) \quad \text { sodalite }
\end{aligned}
$$


and

$$
\begin{aligned}
& 6 \mathrm{NaAlSiO}_{4}+2 \mathrm{NaCl}=\mathrm{Na}_{8} \mathrm{Al}_{6} \mathrm{Si}_{6} \mathrm{O}_{24} \mathrm{Cl}_{2} \\
& \text { carnegieite } \mathrm{NaCl}(v) \quad \text { sodalite. }
\end{aligned}
$$

The decomposition data of WELLMAN (1969b) are most closely matched by the calculated equilibrium for reaction (19) excluding the excess entropy contribution to sodalite (Fig. 2a). Wellman was unable to reverse his decomposition reactions at low $f(\mathrm{NaCl})$ to form sodalite from halite and nepheline. Therefore, the experiments of Wellman represent "half reversals", and are equally consistent with all calculated sodalite-bearing equilibria in Fig. $2 a$ and $b$.

The data of WELLMAN ( $1969 \mathrm{~b}$ ) are more closely matched by the metastable extension of reaction (19) than by reaction (18), and they suggest that sodalite decomposes metastably to carnegieite in the $\gamma$-nepheline stability field at pressures less than 1 bar (Fig. 2a,b). This assumption was tested by simulating the experimental conditions of WELLMAN (1969b) for sodalite decomposition at low $f(\mathrm{NaCl})$. Sodalite, loaded in an open platinum capsule in the end of a long evacuated silica tube, was placed into a horizontal furnace with a constant-temperature region in the center and a region of smoothly decreasing temperature toward the end. The sodalite-bearing end was positioned in the constant temperature region at $1250 \mathrm{~K}$. The temperature at the cool end of the tube was lowcred in 30 minute intervals by sliding the end of the tube away from the hot spot of the furnace until halite could be seen precipitating at the cool end. An X-ray determination of the reaction products confirmed that carnegieite is produced metastably under these conditions.

STORMER and CARMICHAEL (1971) calculated the free energy of sodalite at elevated temperatures assuming that the decomposition temperatures (WELLMAN, 1969b) represent equilibrium conditions for reaction (18) rather than reaction (19). In our study, the free energy of sodalite was calculated from the $973 \mathrm{~K}, 7.5 \pm 0.1 \mathrm{kbar}$ reversal for reaction (9) extrapolated to 1 bar at constant temperature using the equation

$$
\Delta G_{T}^{P}-\Delta G_{T}^{0}=\int_{1 \text { bar }}^{P} \Delta V d P
$$

The free energy of sodalite at 1 bar was then calculated over a broad range of temperature by summing the entropy contributions of the elements as a function of temperature both with and without the excess entropy contribution for sodalite. At $1000 \mathrm{~K}$, the free energy estimate of STORMER and CARMICHAEL (1971) is more negative, and at $1400 \mathrm{~K}$, the estimate of Stormer and Carmichael is less negative than the present estimates (Table 5). This discrepancy is produced by their use of thermodynamic data for nepheline rather than carnegieite. The free energy of sodalite at $973 \mathrm{~K}$, based on the enthalpy data of KOMADA et al. (1989), is slightly more negative than the present estimate (Table 5) and corresponds to an equilibrium pressure of $20 \mathrm{kbar}$ at $973 \mathrm{~K}$ for reaction (9). The very different calculated stability field of sodalite based on the enthalpy data of KOMADA et al. (1989) illustrates the sensitivity of solid-solid reactions to even small differences in free energy estimates.

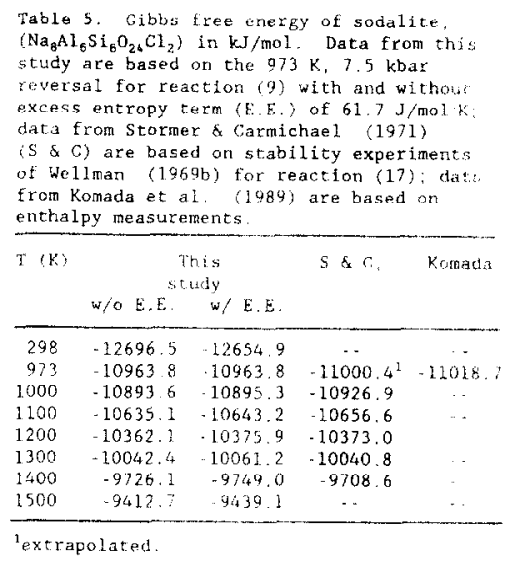

\section{GEOLOGICAL APPLICATIONS}

\section{$\mathrm{NaCl}$ activities in undersaturated magmas}

Sodalite is stable over a broad temperature range, and its presence can be used to constrain the activity of $\mathrm{NaCl}$ in a nepheline-bearing magma. Sodalite is found as euhedral phenocrysts at Mont St-Hilaire, with a coarsely crystalline groundmass of perthitic potassium feldspar, aegirine, nepheline and minor niobium-rich astrophyllite with late-stage albite. Additional late, minor phases, identified with BSE and EDA on the electron microprobe, include serandite, kupletskite, ferroan sphalerite, thorite, elpidite, catapleiite, a mineral of the bastnaesite-synchysite group, thorite and a rare-earth calcium phosphate (cheralite?). In order to calculate activities of $\mathrm{NaCl}$ in the Mont St-Hilaire syenite, estimates of the temperature, pressure and nepheline activity during sodalite crystallization must be made.

Pressure estimates for the Mont St-Hilaire complex are approximately $1 \mathrm{kbar}$, based on stratigraphic relationships (CURRIE et al. 1986). No direct temperature estimates have been made on the sodalite-bearing syenites from Mont StHilaire. However, crystallization experiments of a sodalitebearing naujaite from Ilímaussaq, Greenland (PIOTROwSKI and EDGAR, 1970) show that sodalite is the first phase to crystallize ( $1460 \mathrm{~K}$ at $1 \mathrm{~atm}, 1168 \mathrm{~K}$ at $1 \mathrm{kbar}$ water pressure), and melting experiments in the system $\mathrm{NaAlSiO}_{4}-\mathrm{SiO}_{4}-\mathrm{NaCl}$ $\mathrm{H}_{2} \mathrm{O}$ at 1 kbar indicate that temperatures greater than 1073 $\mathrm{K}$ are required to generate a liquid in the presence of sodalite (BARKER, 1976). Homogenization temperatures of fluid inclusions in nepheline from the sodalite-naujaite from Ilimaussaq are 1123-1313 K (SOBOLEV et al., 1970). All of these data, based on similar rock types, are consistent with high crystallization temperatures in the range of 1073-1300 $\mathrm{K}$ for sodalite-bearing rocks.

The nepheline activity in the Mont St-Hilaire sodalite syenite was set equal to the measured ratio of $\mathrm{Na} /(\mathrm{Na}+\mathrm{K})$ $=0.83$ in the nepheline. This is based on the assumptions that nepheline composition-activity relations are ideal over the solid solution interval $\mathrm{NaAlSiO}_{4}-\mathrm{Na}_{0.75} \mathrm{~K}_{0.25} \mathrm{AlSiO}_{4}$ and that the measured nepheline composition at Mont St-Hilaire has not changed following crystallization. Minimum $\mathrm{NaCl}$ activities of the meit are 0.05 at $1073 \mathrm{~K}$ and 0.13 at $1273 \mathrm{~K}$. As the magma cooled, a highly saline fluid would be evolved (cf., KILINC and BURNHAM, 1972), and NaCl, which is 
strongly partitioned into the aqueous phase, would be removed from the silicate melt. Evidence of this $\mathrm{NaCl}$-rich aqueous fluid is preserved in fluid inclusions with halite daughter salts and salinities of $30 \mathrm{wt} \%$ (F. M. Haynes, pers. commun.).

During the crystallization of a syenitic magma, the $\mathrm{NaCl}$ concentration of the magma and any corresponding fluid phase will change. Crystallization of albite from an albiterich, $\mathrm{NaCl}-\mathrm{H}_{2} \mathrm{O}$-bearing liquid will lead to an increasing concentration of $\mathrm{NaCl}$ and $\mathrm{H}_{2} \mathrm{O}$ in the liquid until a $\mathrm{H}_{2} \mathrm{O}-\mathrm{NaCl}-$ rich fluid (or vapor) develops (KOSTER VAN GROOS and WYLLIE, 1969). In the case of an undersaturated bulk composition with a sufficiently high $\mathrm{NaCl}$ content, sodalite will be the first phase to crystallize (BARKER, 1976), leading to a depletion in the $\mathrm{NaCl}$ content of the residual magma. This will continue until nepheline begins to crystallize. As long as both sodalite and nepheline are present and in equilibrium, the $\mathrm{NaCl}$ activity of the magma will be buffered by reactions (9-12). The $\mathrm{NaCl}$ activity can be calculated from the sodalitenepheline buffer, but the fluid salinities during the early stages of crystallization may only be determined if accurate activitysalinity relationships at elevated pressure and temperatures are known or if primary fluid inclusions in sodalite formed and are preserved. Unfortunately, the fluid inclusions in the Mont St-Hilaire sodalite are secondary, and no comparison of the fluid salinities from these inclusions and $\mathrm{NaCl}$ activities at the temperature of sodalite growth can be made.

\section{Sodalite as an $\mathrm{NaCl}$ buffer in experiments at high pressure and temperatures}

Because sodalite is stable at very high temperatures, it may be used as a buffer in experimental studies of siliceous melts. A wide miscibility gap exists between $\mathrm{NaCl}$-rich liquids and silicate liquids (e.g., KOSTER VAN GROOS and WYLLIE, 1969). The $\mathrm{NaCl}$ activities will be equal in a melt coexisting with a $\mathrm{NaCl}$-saturated aqueous solution, so unit melt activities can be achieved by saturation of $\mathrm{NaCl}$ in the aqueous solution. If sodalite phenocrysts were present in a siliceous melt co-

\begin{tabular}{|c|c|c|c|c|c|c|c|c|c|}
\hline & $\mathrm{WR}^{\mathrm{Mo}}$ & \multicolumn{2}{|c|}{ Mont St-Hilaire } & WR & $\begin{array}{l}\text { Ilimauss } \\
\text { Grour }\end{array}$ & aq & WR & Lovozero & \\
\hline & & $\begin{array}{c}\text { (water } \\
0.0\end{array}$ & $\begin{array}{r}\text { content) } \\
3.73^{3}\end{array}$ & & $\begin{array}{r}\text { (water } \\
0.0\end{array}$ & $\begin{array}{r}\text { content) } \\
2.52\end{array}$ & & $\begin{array}{r}\text { (water } \\
0.0\end{array}$ & $\begin{array}{r}\text { content) } \\
1.48\end{array}$ \\
\hline $1 \mathrm{O}_{2}$ & 47,20 & 63.32 & 60.96 & 46.82 & 54.59 & 53.21 & 47.57 & 54,16 & 53.36 \\
\hline $\mathrm{TiO}_{2}$ & 0.05 & 0.13 & & & & & 0.44 & & 0.69 \\
\hline & n,d. & n.d. & n.d. & 0.4 & 0.70 & 0.68 & 0.37 & 0.59 & 0.58 \\
\hline $\mathrm{Al}_{2} \mathrm{O}_{3}$ & 26.40 & 19.41 & 28.69 & 22.42 & 16.87 & 16.44 & 21.90 & 16.45 & 16.21 \\
\hline $\mathrm{Fe}_{2} \mathrm{O}_{3}$ & 1.23 & 3.09 & 2.98 & 3.00 & 5.11 & 4.98 & 5.18 & 8.2 & 8.15 \\
\hline$e^{4}$ & n.d. & n.d. & n.d. & 2.10 & 3.57 & 3.48 & 0.85 & 1.36 & 1.34 \\
\hline Mno & 0.12 & 0.30 & 0.29 & 0.13 & 0.22 & 0.22 & 0.38 & & 0.60 \\
\hline & 0.06 & 015 & & 0.16 & 0.27 & 0.27 & 0.34 & 0.54 & 0.54 \\
\hline $\mathrm{CaO}$ & 0.21 & 0.53 & 0.51 & 1.24 & 2.11 & 2.06 & 0.66 & 1. & 1.04 \\
\hline $\mathrm{Na}_{2} \mathrm{O}$ & 17.70 & 6.44 & 6.20 & 15.93 & 9.86 & 9.61 & 12.78 & & 5.31 \\
\hline & 2.58 & 6.49 & 6.24 & 3.61 & 6.1 & 5.99 & 5.58 & 8. & 8.78 \\
\hline $\mathrm{P}_{2}^{2} \mathrm{O}_{3}$ & 0.02 & 0.05 & 0.05 & 0.03 & 0.0 & 0.05 & 0.71 & 1.13 & 1.12 \\
\hline & 0.04 & 0.10 & 0.10 & 0.0 & 0.6 & 0.0 & & & 0.80 \\
\hline $\mathrm{ci}_{2}$ & 4.73 & 0.00 & 0.00 & 2,90 & 0.00 & 0.00 & 2.69 & 0.00 & 0.00 \\
\hline $\mathrm{H}_{2} \mathrm{O}$ & n.d. & 0.00 & $3.73^{\circ}$ & 1.52 & 0.00 & 2.52 & 0.94 & 0.00 & 1.48 \\
\hline LOI & 1.54 & & & $\ldots$ & & & & & \\
\hline Total & 101.88 & 100.00 & 100.00 & 100.57 & 100.00 & 100.00 & 100.90 & 100.00 & 100.00 \\
\hline$-0-C 1$ & 1.07 & & & 0.65 & & & 0.61 & & \\
\hline Total & 100.81 & & & 99.92 & & & 100.29 & & \\
\hline
\end{tabular}

Table 7. Sodalite density and melt densities for anhydrous and hydrous conditions. Data in $\mathrm{gm} / \mathrm{cm}^{3}$. BWR - Bottinga et al. (1982); LáC - Lange and Carmichael (1987).

\begin{tabular}{|c|c|c|c|c|c|c|c|c|c|c|}
\hline & \multirow[t]{4}{*}{ sodalite } & \multicolumn{3}{|c|}{ melt } & \multicolumn{3}{|c|}{ melt } & \multicolumn{3}{|c|}{ me1t } \\
\hline & & \multicolumn{3}{|c|}{ Mont St-HIlaire } & \multicolumn{3}{|c|}{ Ilfmaussaq } & \multicolumn{3}{|c|}{ Lovozero } \\
\hline & & BWR & LSC & LAC & BWR & LSC & L\&C & $\mathrm{BWR}$ & LsC. & $\mathrm{LSC}$ \\
\hline \multirow[b]{2}{*}{$T(K)$} & & \multicolumn{3}{|c|}{ water content } & \multicolumn{3}{|c|}{ water content } & \multicolumn{3}{|c|}{ water content } \\
\hline & & 0.00 & 0.00 & 4.26 & 0.00 & 0.00 & 2.52 & 0.00 & 0.00 & 1.48 \\
\hline 1000 & 2.23 & 2.49 & 2.56 & 2.34 & 2.60 & 2.70 & 2,54 & 2.68 & 2.71 & 2.62 \\
\hline 1200 & 2.21 & 2.46 & 2.53 & 2.26 & 2.55 & 2.65 & 2.47 & 2.63 & 2.67 & 2.55 \\
\hline 1400 & 2.18 & 2.43 & 2.51 & 2.19 & 2.50 & 2.61 & 2.39 & 2.58 & 2.63 & 2,49 \\
\hline 1600 & 2.16 & 2.40 & 2.48 & 2.11 & 2.45 & 2.57 & 2.32 & 2.53 & 2.59 & 2.43 \\
\hline
\end{tabular}

existing with a $\mathrm{NaCl}$-saturated aqueous fluid, the activity of $\mathrm{NaAlSiO}_{4}$ will be buffered by reaction (1) and can be uniquely determined from the thermodynamic data in Table 4 . This buffer may prove useful in studies of species activity in appropriate silicate liquids.

\section{Buoyancy of sodalite in magmas}

As a result of its large open framework struclure, the density of sodalite is very low. Sodalite is found as phenocrysts in the upper levels of the Mont St-Hilaire syenite, in the Ilimaussaq sodalite-syenites, South Greenland (UssING, 1912; SORENSEN, 1958) and in the Lovozero intrusion, Kola Peninsula, West Soviet Union (VLASOV et al., 1966). The stratification of the sodalite-bearing layers at Ilimaussaq has been attributcd to sodalite flotation (USSING, 1912, p. 352). Studies of liquid and crystal densities will permit evaluation of crystal flotation under a variety of conditions (e.g., BOTTINGA and WEILL, 1970; CAMPBELL et al., 1978; STOLPER et al., 1981; IRVINE, 1987). Sodalite buoyancy could explain the stratification in these large alkali intrusions and also the local reverse zonation (downward enrichment) of silica in the Il'maussaq and Lovozero intrusions. In order to test this hypothesis, the density of both the sodalite and the magma must be known under the conditions of sodalite crystallization, and the viscosity of the magma must be estimated to calculate rates of sodalite removal by flotation.

Direct density measurements were made on $5 \mathrm{~g}$ of Mont St-Hilaire sodalite in a Berman balance with toluene as the immersion fluid. The measured density, $2.276(5) \mathrm{g} / \mathrm{cm}^{3}$, is identical to the calculated value of 2.276 from a molecular weight of $959.7 \mathrm{~g} / \mathrm{mol}$ from the sodalite analysis of the Mont St-Hilaire sodalite (Table 1) and a unit cell volume of 421.56 $\mathrm{cm}^{3} / \mathrm{mol}$ ( Table 2 ). The density of sodalite can be calculated at elevated temperatures by combining the high-temperature volume data of HENDERSON and TAYLOR (1978) with the room temperature density determination. In order to determine the density of the melt coexisting with sodalite, the composition of the melt must be estimated. The melt com-

\begin{tabular}{|c|c|c|c|c|c|c|}
\hline \multirow[t]{2}{*}{$T(K)$} & \multicolumn{2}{|c|}{ MSH } & \multicolumn{2}{|c|}{ I 1 imaus s aq } & \multicolumn{2}{|c|}{ Lovozero } \\
\hline & $\begin{array}{l}\text { wat } \\
0.0\end{array}$ & $\begin{array}{l}\text { er con } \\
4.26\end{array}$ & $\begin{array}{c}\text { nt (w } \\
0.0\end{array}$ & $\begin{array}{c}3.52 \\
2.52\end{array}$ & 0.0 & 1.48 \\
\hline 1000 & 10.51 & 6.51 & 7.06 & 5.39 & 8.66 & 7.47 \\
\hline 1200 & 7.91 & 4.69 & 5.13 & 3.79 & 6.41 & 5.46 \\
\hline 1400 & 6.05 & 3.39 & 3.75 & 2.64 & 4.81 & 4.02 \\
\hline 1600 & 4.65 & 2.41 & 2.72 & 1.79 & 3.61 & 2.95 \\
\hline
\end{tabular}




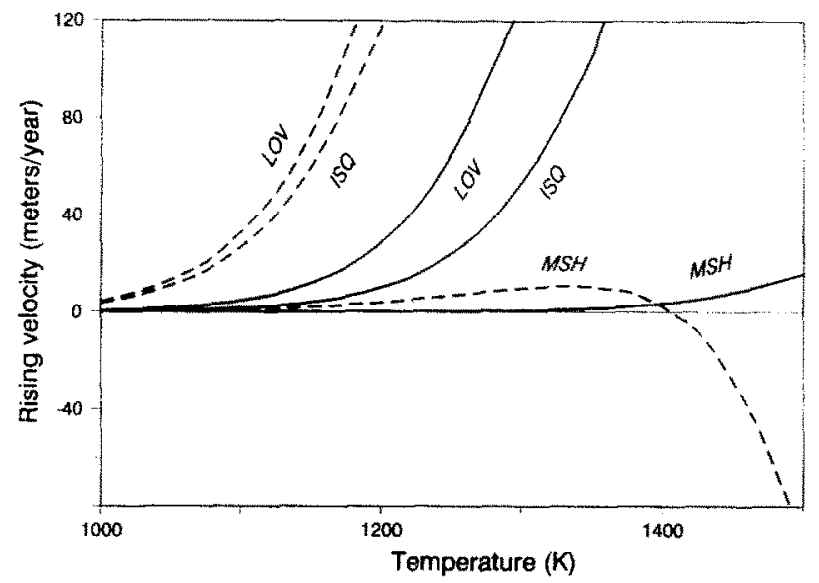

FIG. 3. Rising velocities of sodalite phenocrysts ( $3 \mathrm{~mm}$ grain radius) in coexisting melt calculated from Stokes law. Density data from Table 7; viscosity data from Table 8 . Solid lines = anhydrous melt, dashed lines $=$ wet melt. ISQ $=$ Ilímaussaq, LOV $=$ Lovozero, $M S H$ $=$ Mont St-Hilaire.

position coexisting with the sodalite phenocrysts is assumed to be the same as the groundmass bulk composition. The groundmass composition was estimated by subtracting the appropriate sodalite components in proportion to the total amount of chlorine in the analysis. The water content of the magma was bracketed between $0 \mathrm{wt} \%$ and the water content from the chemical analysis after the removal of the sodalite component. Melt densities are calculated from the models of BOTTINGA et al. (1982) and LANGE and CARMICHAEL (1987). The partial molar volume data for $\mathrm{H}_{2} \mathrm{O}$ are from the model of BURNHAM and DAVIS (1971) for the albite-water system assuming $3 w t \%$ water in the melt. Magma viscosities are determined from the viscosity data of SHAW (1972).

Whole-rock and calculated groundmass compositions for Mont St-Hilaire, Ilimaussaq and Lovozero are presented in Table 6. The extremely high Cl content of the Mont St-Hilaire analysis leads to a quartz normative calculated groundmass composition. This high chlorine content of the Mont St Hilaire whole rock sample and the purified sodalite was checked by standard wet chemical methods. Samples were finely ground, heated to $500^{\circ} \mathrm{C}$ for 10 minutes to decrepitate any fluid inclusions and washed in deionized water. Repetitive analyses yield $7.62 \pm 0.18$ and $4.64 \pm 0.10 \mathrm{wt} \% \mathrm{Cl}$ for the sodalite and whole rock, respectively. The measured chlorine content for the sodalite is $0.3 \mathrm{wt} \%$ above the $7.3 \mathrm{wt} \%$ maximum for a stoichiometric sample. If $0.3 \mathrm{wt} \% \mathrm{Cl}$ is subtracted from both the sodalite and the whole-rock sample, then a stoichiometric sodalite and a nepheline normative groundmass composition result. All further calculations were made assuming $4.3 \mathrm{wt} \%$ chlorine for the groundmass composition of the Mont St-Hilaire sample. Calculated maximum water contents of 1.5-3.4 wt\% $\mathrm{H}_{2} \mathrm{O}$ from Mont St-Hilaire, Ilimaussaq and Lovozero are in agreement with estimates of KOSTER VAN GROOS and WYLLIE (1969) and CARMICHAEL et al (1974) for maximum water contents of similar magma chemistries.

Sodalite and melt densities from 1000 to $1600 \mathrm{~K}$ are presented in Table 7 for varying water contents. Viscosity estimates for these melts over the same temperature range are presented in Table 8 . Above $1200 \mathrm{~K}$, buoyancy velocities calculated from Stokes law are, in nearly all cases, rapid enough to allow significant reverse cumulation to occur over a period of approximately 1000 years (Fig. 3)

Although sodalite-bearing syenites are rare, their unique chemistry illustrates different properties that occur in igneous processes. The driving force for sodalite buoyancy highlights the importance of crystal settling (and flotation) in large magma chambers and its importance in magma genesis of alkaline rocks.

Acknowledgements-This work was supported in part by NSF grants FAR-84-08168 to EJ.E and EAR-86-15714 to S.R.B. The authors would like to thank A. Bloomfield for XRF analyses, D. J. Velinsky for help with the wet chemical analysis, G. E. Muncill for help with the ICP analyses, and S. W. Sharp, H. S. Yoder, Jr., A. Koster Van Groos and K. L. Currie for their valuable reviews. The electron microprobe analyzer at the University of Michigan used in this work was acquircd under NSF grant EAR-82-12764.

\section{Editorial handling: B. J. Wood}

\section{REFERENCES}

AUTEFAGE F. (1980) Variations de la teneur en sodium et en potassium dans des minéraux au cours de leur analyse à la microsonde électronique. Bull. Minéral. 103, 48-53.

BARKER D. S. (1976) Phase relations in the system $\mathrm{NaAlSiO}_{4}-\mathrm{SiO}_{2}-$ $\mathrm{NaCl}-\mathrm{H}_{2} \mathrm{O}$ at $400^{\circ}-800^{\circ} \mathrm{C}$ and 1 kilobar, and petrologic implications. J. Geol. 84, 97-106.

Beagley B., Henderson C. M. B. and TAYLor D. (1982) The crystal structures of aluminosilicate-sodalites: X-ray diffraction studies and computer modeling. Mineral. Mag. 46, 459-464.

Binsted N. (1981a) The system Ab-Ne-NaCl-H ${ }_{2} \mathrm{O}$. Prog, Exp. Petrol., N.E.R.C. Rept. 5, 34-36.

BiNSTED N. (1981b) The stability of sodalite minerals. Prog. Exp. Petrol., N.E.R.C. Rept. 5, 54-56.

BIRCH F. ( 1966 ) Compressibility: elastic constants. In Handbook of Physical Constants (ed. S. P. Clark, JR.); Geol. Soc. Amer, Mem. 97. pp. 97-174.

BoETrCHER A. L. and WYLLIE P. J. (1968) Jadeite stability measured in the presence of silicate liquids in the system $\mathrm{NaAlSiO}_{4}-\mathrm{SiO}_{2}$ $\mathrm{H}_{2} \mathrm{O}$. Geochim. Cosmochim. Acta 32, 999-1012.

BOHLEN S. R. (1984) Equilibria for precise pressure calibration and a frictionless furnace assembly for the piston-cylinder apparatus. N. Jb. Mineral. Mh. 1984, 404-412.

BOTTINGA Y. and WenLL D. (1970) Densities of liquid silicate systems calculated from partial molar volumes of oxide components. Amer. J. Sci. 269, 169-182.

Botmnga Y., WeILL D. and RiCheT P. (1982) Density calculations for silicate liquids. I. Revised methods for aluminosilicate compositions. Geochim. Cosmochim. Acta 46, 909-919.

BoweN N. L. (1912) The binary system: $\mathrm{Na}_{2} \mathrm{Al}_{2} \mathrm{Si}_{2} \mathrm{O}_{8}$ (nephelite, carnegieite)- $\mathrm{CaAl}_{2} \mathrm{Si}_{2} \mathrm{O}_{6}$ (anorthite). Amer. J. Sci. 33, 551-573

BOWEN N. L. and GREIG N. L. (1925) The crystalline modifications of NaAlSiO 4 . Amer. J. Sci. 10, 204-215.

BROUSSE R., VARET J. and BIZOUARD H. (1969) Iron in the minerals of the sodalite group. Contrib. Mineral. Petrol. 22, 169-184.

BURNHAM C. W. and DAVIS N. F. (1971) The role of $\mathrm{H}_{2} \mathrm{O}$ in silicate melts I. $P-V$ - $T$ relations in the system $\mathrm{NaAlSi}_{3} \mathrm{O}_{8}-\mathrm{H}_{2} \mathrm{O}$ to 10 kilobars and $1000^{\circ}$ C. Amer. J. Sci. 270, 54-79.

CAMPBell I. H., ROEDER P. L. and DixoN J. M. (1978) Plagioclase buoyancy in basaltic liquids as determined with the centrifuge furnace. Contrib. Mineral. Petrol. 67, 369-377.

CARMichael I. S. E., TURNer F. J. and VerhoOgen J. (1974) Igneous Petrology. McGraw-Hill, 739p.

Chase M. W., JR., Davies C. A., Downey J. R., JR, FruRip D. J., MCDONALD R. A. and SYVERUD A. N. (1985) JANAF Thermochemical Tables, 3rd edn., Vol. 14, Amer. Chem. Soc., Midland, MI, 926p. 
ClaRK S. P. (1959) Effect of pressure on the melting points of eight alkali halides. $J$. Chem. Phys. 31, 1526-1531.

COHEN L. H. and KLEMENT W., JR. (1976) Effect of pressure on reversible solid-solid transitions in nepheline and carnegieite. Mineral. Mag. 40, 487-492.

CURRIE K. L., EBY G. L. and Girtins J. (1986) The petrology of the Mont Saint Hilaire complex, southern Quebec: An alkaline gabbro-peralkaline syenite association. Lithos 19, 65-81.

DEER W. A., HowIE R. A. and ZuSSMAN J. (1963) Rock-Forming Minerals, Vol. 4. Wiley. 435p

DEMIDENKo V. A., ASTAKHOVA V. V. and Volynets F. K. (1983) The structural transitions of sodalite. Kristallografiya 28, 593-595.

DONNAY G., SCHAIRER J. F. and DONNAY J. D. H. (1959) Nepheline solid solutions. Mineral. Mag. 32, 93-109.

FyFe W. S., TURner F. J. and Verroogen J. (1958) Metamorphic reactions and metamorphic facies. Geol. Soc. Amer. Mem. 73, 259p.

GOLDSMITH J. R. and JENKINS D. M. (1984) The high-low albite relations revealed by reversal of degree of order at high pressures. Amer. Mineral. 70, 911-923.

GrossMAN L. and STEELE I. M. (1976) Amoeboid olivine aggregates in the Allende meteorite. Geochim. Cosmochim. Acta 40, 149155.

HAMLTON E. I. (1964) The geochemistry of the northern part of the llimaussaq intrusion, S. W. Greenland. Medd. Gremland 162, $1-104$.

HASSAN I. and GRUNDY H. D. (1984) The crystal structures of sodalite-group minerals. Acta Cryst. B40, 6-13.

HAYS J. F. and BELL P. M. ( 1973 ) Albite-jadeite-quartz equilibrium: A hydrostatic determination. Carnegie Inst. Wash. Yb. 72, 706708 .

HAZEN R. M. and SHARP Z. D. (1988) Compressibility of the framework silicates sodalite and scapolite. Amer. Mineral. 73, 1120 1122.

HelfFrich G. R., SHARP Z. D. and ESSENE E. J. (1986) Thermodynamics of sodalite and implications of sodalite presence in syenitic systems. Eos 67, 389.

Helgeson H. C., Delany J. M., Nesbitt H. W. and Bird D. K. (1978) Summary and critique of the thermodynamic properties of rock-forming minerals. Amer. J. Sci. 278a, 1-229.

HENDERSON C. M. B. and RouX J. (1976) The thermal expansions and crystallographic transformations of some synthetic nephelines. Prog. Exp. Petrol., N.E.R.C. Rept. 3, 60-69.

Henderson C. M. B. and RouX J. (1977) Inversions in sub-potassic nephelines. Contrib. Mineral. Petrol 61, 279-298.

HENDERSON C. M. B. and TAYLOR D. (1978) The thermal expansion of synthetic aluminosilicate-sodalites, $M_{8}\left(\mathrm{Al}_{6} \mathrm{Si}_{6} \mathrm{O}_{24}\right) X_{2}$. Phys. Chem. Mineral. 2, 337-347.

HENDERSON C. M. B. and TAYLOR D. (1979). Infrared spectra of aluminogermanate- and aluminate-sodalites, and a re-examination of the relationship between $T-O$ bond length, $T-O-T$ angle and the position of the main $I R$ absorption band for compounds with framework structures. Spectrochim. Acta A:35, 925-935.

HeNDeRson C. M. B. and Thompson A. B. (1980) The low-temperature inversion in sub-potassic nephelines. Amer. Mineral. 65, 970-980.

HUMmel F. A. (1949) Properties of some substances isostructural with silica. J. Amer. Ceram. Soc. 32, 320-326.

IRVINE T. N. (1987) Layering and related structures in the Duke Island and Skaergaard intrusions: similarities, differences, and origins. In Origins of Igneous Layering (ed. I. PARSONS), pp. 185245. D. Reidel Publishing.

JANZ G. J. (1967) Molten Salts Handbook. Academic Press, 588p.

JOHANNES W. (1978) Pressure comparing experiments with $\mathrm{NaCl}$, $\mathrm{AgCl}$, talc, pyrophyllite assemblies in a piston-cylinder apparatus. N. Jb. Mineral. Mh. 1978(2), 84-92.

KFILEY K, K., TODD S. S., ORR R. L., KING E. G. and BONNICKSON K. R. (1953) Thermodynamic properties of sodium-aluminum and potassium-aluminum silicates. U.S. Bur. Mines Rept. 4955, $21 \mathrm{p}$.

KILINC I. A. and BURNHAM C. W. (1972) Partitioning of chloride between a silicate melt and coexisting aqueous phase from 2 to 8 kilobars. Econ. Geol, 67, 231-235.

KLINGENBERG R. and FelsCheR J. (1981) Crystal data for the low- temperature form of carnegieite $\mathrm{NaAlSiO}_{4} . J$. Appl. Cryst. 14, 6668.

KLINOWSKi J., CARR S. W., TARLING S. E. and BARNES P. (1987) Magic-angle-spinning NMR shows the aluminosilicate framework of ultramarine to be disordered. Nature 330, 56-58.

Komada N., WeSTrum E. F., JR., HemingWaY B. S., Zolotov M. Y., SEMENOV Y. V., KHODAKOVSKY I L and ANOVITZ L. M. (1989) Thermodynamic properties of sodalite from 15 to $1000 \mathrm{~K}$ J. Chem. Therm. (in prep.).

Koster VAN Groos A. F. and Wyllie P. J. (1969) Melting relationships in the system $\mathrm{NaAlSi}{ }_{3} \mathrm{O}_{8}-\mathrm{NaCl}-\mathrm{H}_{2} \mathrm{O}$ at one kilobar pressure, with petrological applications. J. Geol. 77, 581-605.

LANGE R. A. and CARMICHAEL I. S. E. (1987) Densities of $\mathrm{Na}_{2} \mathrm{O}$ $\mathrm{K}_{2} \mathrm{O}-\mathrm{CaO}-\mathrm{MgO}-\mathrm{FeO}-\mathrm{Fe}_{2} \mathrm{O}_{3}-\mathrm{Al}_{2} \mathrm{O}_{3}-\mathrm{TiO}_{2}-\mathrm{SiO}_{2}$ liquids: New measurements and derived partial molar properties. Geochim. Cosmochim. Acta 51, 2931-2946.

Lu L. (1977) High pressure $\mathrm{NaAlSiO}_{4}$ : The first silicate calcium ferrite isotype. Geophys. Res. Lett. 4, 183-186.

LOEWENSTEIN W. (1954) The distribution of aluminum in the tetrahedra of silicates and aluminates. Amer. Mineral. 39, 92-96.

LONS J. and SCHULZ H. (1967) Strukturverfeinerung von Sodalith, $\mathrm{Na}_{8} \mathrm{Si}_{6} \mathrm{Al}_{6} \mathrm{O}_{24} \mathrm{Cl}_{2}$. Acta Cryst. 23, 434-436.

LUMPKIN G. R. (1980) Nepheline and sodalite in a barred olivine chondrule from the Allende meteorite. Meteoritics 15, 139-147.

MCCONNELL J. D. C. (1981) Time-temperature study of the intensity of satellite reflections in nepheline. Amer. Mineral. 66, 990-996.

Mirwald P. W., GetTing I. C. and KenNedy G. C. (1975) Lowfriction cell for piston-cylinder high-temperature apparatus. $J$. Geophys. Res. 80, 1519-1525.

NEWTON M. S. and KENNEDY G. C. (1968) Jadeite, analcite, nepheline, and albite at high temperatures and pressures. Amer. J. Sci. 266, 728-735.

PETERSON R. C. (1983) The structure of hackmanite, a variety of sodalite from Mont St-Hilaire, Quebec. Can. Mineral. 21, 549552.

Plotrowski J. M. and EdGAR A. D. (1970) Melting relations of undersaturated alkaline rocks from South Greenland, Medd. Gronland 181, 1-62.

ROBIE R. A., HEMingway B. S. and Fisher J. R. (1978) Thermodynamic properties of minerals and related substances at 298.15 $\mathrm{K}$ and 1 bar $\left(10^{5}\right.$ pascals $)$ pressure and at higher temperatures. U.S. Geol. Surv. Bull. 1452,456 p. (reprinted with corrections).

RoBinson G. R., JR. and HAAS J. L., JR. (1983) Heat capacity, relative enthalpy, and calorimetric entropy of silicate minerals: an empirical method of prediction. Amer. Mineral. 68, 541-553.

ROBINSON G. R., JR., HAAS J. L, JR , SCHAFER C. M. and HASELTON H. T., JR. ( 1982) Thermodynamic and thermophysical properties of selected phases in the $\mathrm{MgO}-\mathrm{SiO}_{2}-\mathrm{H}_{2} \mathrm{O}-\mathrm{CO}_{2}, \mathrm{CaO}-\mathrm{Al}_{2} \mathrm{O}_{3}-\mathrm{SiO}_{2}$. $\mathrm{H}_{2} \mathrm{O}-\mathrm{CO}_{2}$, and $\mathrm{Fe}-\mathrm{FeO}-\mathrm{Fe}_{2} \mathrm{O}_{3}-\mathrm{SiO}_{2}$ chemical systems, with special emphasis on the properties of basalts and their mineral components. U.S. Geol. Sur. Open-File Rept. 83-79, 429p.

ROEDDER E. (1984) Fluid Inclusions; Reviews in Mineralogy 12 Mineral. Soc. Amer., 644p.

RoY D. M. and RoY R. (1969) The carnegieite-nepheline and cristobalite-tridymite transition. Ind. Mineral. 10, 16-22.

Semenov Y. V., Sidorov Y. I., Khodakovski I. L., ZhdanoV V. M. and TURDAKIM V. A. (1981) Standard entropy of minerals Vses. Soveshch. Eksp. Tekh. Mineral. Petrogr., (Mater.), 10th. (ed Y. P. MEL'NIK and D. NAUKOVA), pp. 96-102. Kiev, U.S.S.R.

SHANNON R. D. and BERZINS T. (1979) lonic conductivity in low carnegieite compositions based on $\mathrm{NaAlSiO}_{4}$. Mat. Res. Bull. 14, $361-367$.

SHAW H. R. (1972) Viscosities of magmatic silicate liquids: an empirical method of prediction. Amer. J. Sci. 272, 870-893.

Simpson E. S. W, and OTto J. D. T. (1960) On the Pre-Cambrian anorthosite mass of southern Angola. Rept. 21st Intern. Geol. Congr., Norden 13, 216-227.

SKINNER B. J. (1966) Thermal expansion. In Handbook of Physical Constants. (ed. S. P. CLARK, JR.); Geol. Soc. Amer. Mem. 97, pp. $75-96$.

SMITH J. V. and TUTTLE O. F. (1957) The nepheline-kalsilite system: I. X-ray data for the crystalline phases. Amer. J. Sci $255,282-$ 305. 
Sobolev V. S., Bazarova T. Y., Shigurova N. A., Ba7arov L. SH., Dolgov Yu. A. and SOrenSEN H. (1970) A preliminary examination of fluid inclusions in nepheline, sorensenite, tugtupite and chkalovite from the Ilimaussaq alkaline intrusion, South Greenland. Medd. Gronland 181, 1-32.

SORENSEN H. (1958) The llimaussaq batholith, a review and discussion. Medd. Gronland 162, 1-48.

Stopler E., Walker D., Hager B. H. and Hays J. F. (1981) Melt segregation from partially molten source regions: the importance of melt density and source region size. J. Geophys. Res. 86, 62616271 .

Stormer J. C. and Carmichael I. S. E. (1971) The free energy of sodalite and the behavior of chloride, fluoride and sulfate in silicate melts. Amer. Mineral. 56, 292-306.

ThOMPSON A. B. and PERKINS E. H. (1981) Lambda transitions in minerals. In Thermodynamics of Minerals and Melts (ed. R. C. Newton, A. Navrotsky and B. J. Wood); Adv. in Phys. Geochem. I, pp. 35-62.

TomisakA T. and Eugster H. P. (1968) Synthesis of the sodalite group and subsolidus equilibria in the sodalite-noselite system. Mineral. J. 5, 249-275.

TUTTLE O. F. and SMITH J. V. (1958) The nepheline-kalsilite system: II. Phase relations. Amer. $J$. Sci. 256, 571-589.
Ussing N. V. (1912) Geology of the country around lulianehaah. Greenland. Medd. Gronland 38, 1-376.

VLASOV K. A., KuZ'MENKO M. Z. and Es'Kova E. M. (1966) The' Lovozero Alkali Massif. Hafner Publishing, 627p.

WELLMAN T. R. (1969a) The stability of sodalite in the system $\mathrm{NaAlSi}_{3} \mathrm{O}_{8}-\mathrm{KAlSi}_{3} \mathrm{O}_{8}-\mathrm{NaAlSiO}_{4}-\mathrm{KAISiO}_{4}-\mathrm{NaCl}-\mathrm{KCl}-\mathrm{H}_{2} \mathrm{O}$. Ph.D. dissertation, Yale Univ.

WELLMAN T. R. (1969b) The vapor pressure of NaCl over decomposing sodalite. Geochim. Cosmochim. Acta 33, 1302-1303.

WELLMAN T. R. (1970a) The stability of sodalite in a synthetic syenite plus aqueous chloride fluid system. J. Petrol. 11, 49-71.

WELLMAN T. R. ( 1970b) Fugacities and activity coefficients of $\mathrm{NaCl}$ in $\mathrm{NaCl}-\mathrm{H}_{2} \mathrm{O}$ fluids at elevated temperatures and pressures. Amer. J. Sci. 269, 402-413.

WESTRUM E. F., JR. (1974) Calorimetry of phase and ordering transitions. Pure Appl. Chem. 38, 539-555.

WOOD B. J. and FRASER D. G. (1977) Elementary Thermodynamics for Geologists. Oxford Univ. Press, 303p.

Zolotov M. Y., SEMENOV Y. V., SidoRov Y. I., ZhDanov V. M. and TURDAKIM V.A. (1982) Thermodynamic properties of sodalite. In Papers of All-Union Conference. Problems of Calorimetry and Chemical Thermodynamics, Vol. 2, pp. 451-453. Chernogolovka. 